\title{
Circadian control of neuroendocrine circuits regulating female reproductive function
}

\section{Wilbur P. Williams III and Lance J. Kriegsfeld*}

Department of Psychology, Helen Wills Neuroscience Institute, University of California, Berkeley, CA, USA

\section{Edited by:}

Henryk Urbanski, Oregon National

Primate Research Center, USA

\section{Reviewed by:}

Patrick Chappell, Oregon State

University, USA

Xavier Bonnefont, CNRS, France

Tomoshige Kino, Eunice Kennedy

Shirver National Institute of Child

Health and Human Development,

USA

\section{${ }^{*}$ Correspondence:}

Lance J. Kriegsfeld, Neurobiology

Laboratory, Department of

Psychology, Helen Wills

Neuroscience Institute, University of California, 3210 Tolman Hall, \#1650

Berkeley, CA 94720-1650, USA.

e-mail: kriegsfeld@berkeley.edu
Female reproduction requires the precise temporal organization of interacting, estradiolsensitive neural circuits that converge to optimally drive hypothalamo-pituitary-gonadal (HPG) axis functioning. In mammals, the master circadian pacemaker in the suprachiasmatic nucleus (SCN) of the anterior hypothalamus coordinates reproductively relevant neuroendocrine events necessary to maximize reproductive success. Likewise, in species where periods of fertility are brief, circadian oversight of reproductive function ensures that estradiol-dependent increases in sexual motivation coincide with ovulation. Across species, including humans, disruptions to circadian timing (e.g., through rotating shift work, night shift work, poor sleep hygiene) lead to pronounced deficits in ovulation and fecundity. Despite the well-established roles for the circadian system in female reproductive functioning, the specific neural circuits and neurochemical mediators underlying these interactions are not fully understood. Most work to date has focused on the direct and indirect communication from the SCN to the gonadotropin-releasing hormone $(\mathrm{GnRH})$ system in control of the preovulatory luteinizing hormone (LH) surge. However, the same clock genes underlying circadian rhythms at the cellular level in SCN cells are also common to target cell populations of the SCN, including the $\mathrm{GnRH}$ neuronal network. Exploring the means by which the master clock synergizes with subordinate clocks in $\mathrm{GnRH}$ cells and its upstream modulatory systems represents an exciting opportunity to further understand the role of endogenous timing systems in female reproduction. Herein we provide an overview of the state of knowledge regarding interactions between the circadian timing system and estradiol-sensitive neural circuits driving $\mathrm{GnRH}$ secretion and the preovulatory LH surge.

Keywords: suprachiasmatic, ovulation, kisspeptin, GnIH, RFRP-3, AVP, VIP

\section{INTRODUCTION}

The neural mechanisms regulating ovulation are under circadian control in many species, ensuring that the timing of greatest fertility coincides the period of maximal sexual motivation (Nequin et al., 1975; Sarkar et al., 1976). Superimposed upon this circadian control is a dependence of the reproductive cycle on estradiol to ensure proper maturation of the oocyte at the time of ovulation. The precise timing in the initiation of ovulation by a central, $24 \mathrm{~h}$ clock was first identified in a classic study by Everett and Sawyer (1950) who described the "neurogenic activation of the hypophysis" as a necessary component of ovulation. In this seminal paper, Everett and Sawyer reported that injections of barbiturate, within a 2-h time window, were capable of delaying ovulation in female rats by $24 \mathrm{~h}$. Administration outside of this critical time window failed to prevent ovulation. Because the impact of the barbiturate injections was short-lived, whereas ovulation was delayed precisely 1 day, the authors postulated that a daily, neural signal triggers ovulation.

In mammals, a master pacemaker located in the suprachiasmatic nucleus (SCN) of the hypothalamus orchestrates circadian timing (Moore and Eichler, 1972; Stephan and Zucker, 1972). Circadian rhythms are endogenously generated (Lehman et al., 1987; Ralph et al., 1990) and synchronized to the external environment via direct neural projections from intrinsically photosensitive retinal ganglion cells to the circadian clock in the SCN (Berson et al., 2002; Hattar et al., 2002; Panda et al., 2002; Provencio et al., 2002; Ruby et al., 2002; Morin and Allen, 2006). The SCN communicates to neuroendocrine cells driving reproductive function through extensive direct and indirect neural projections (Boden and Kennaway, 2006; de la Iglesia and Schwartz, 2006; Kriegsfeld and Silver, 2006; Christian and Moenter, 2010). More recently, it has become evident that the gonadotropin-releasing hormone $(\mathrm{GnRH})$ system does not respond passively to $\mathrm{SCN}$ signaling, but contains the same circadian clock "machinery" necessary to generate autonomous cellular oscillations, and these subordinate clocks likely mediate daily changes in sensitivity to SCN communication (Chappell et al., 2003; Gillespie et al., 2003; Resuehr et al., 2007; Zhao and Kriegsfeld, 2009; Tonsfeldt et al., 2011; Williams et al., 2011). Disruptions to $\mathrm{SCN}$ output signaling pathways or intrinsic activity of the cellular clockwork lead to gross deficits in female rodent ovulatory function and fecundity (Nunez and Stephan, 1977; Gray et al., 1978; Wiegand and Terasawa, 1982; Miller et al., 2004). The following sections will summarize the present understanding of interactions between the circadian system and estradiol responsive circuits required for mammalian female reproductive functioning and success. 


\section{CIRCADIAN CONTROL OF THE PREOVULATORY LH SURGE}

Throughout the ovulatory cycle, concentrations of sex steroids and consequent stimulation of the developing ovarian follicle are controlled by a neuroendocrine cascade beginning with the secretion of hypothalamic GnRH into the hypophyseal portal system. In turn, GnRH acts on the anterior pituitary to stimulate the synthesis and secretion of the gonadotropins, luteinizing hormone (LH) and follicle-stimulating hormone (FSH). LH and FSH then act on the gonads to regulate steroidogenesis and gametogenesis, respectively. The activity of the reproductive axis is controlled through the action of negative feedback effects of sex steroids, with this mechanism maintaining LH at low concentrations throughout most of the ovulatory cycle. In many spontaneously ovulating species, the preovulatory LH is initiated by the SCN on the day of proestrus, at a time closely preceding activity onset (Legan and Karsch, 1975; Mahoney et al., 2004; Chappell, 2005; Gibson et al., 2008). Paradoxically, high concentrations of estradiol are required for the SCN to trigger ovulation (i.e., positive feedback; Legan and Karsch, 1975; de la Iglesia and Schwartz, 2006; Kriegsfeld and Silver, 2006; Christian and Moenter, 2010). The site(s) of integration for positive and negative feedback effects of estradiol with the circadian timing system are complex and not fully understood. Moreover, it is unclear whether a single system participates in both negative and positive feedback, whether two independent systems differentially dominate throughout the cycle, or a combination of these two mechanisms of control determine the onset of the preovulatory GnRH surge.

To explore the role of the circadian system in female reproductive behavior, Syrian hamsters (Mesocricetus auratus) are frequently employed as a model system due to the exquisite precision in their circadian rhythms and reproductive behavior. When held in a light:dark (LD) cycle, for example, ovulation and the onset of behavioral receptivity occur precisely every $96 \mathrm{~h}$ in this species (Alleva et al., 1971). This rhythm in reproductive activity is endogenously generated and persists in constant conditions with a period four times their free-running circadian period. This fact was confirmed by investigating heat onset (i.e., propensity to display lordosis, the gonadotropin surge and vaginal cytology) in individual hamsters housed in constant darkness (DD) prior to and after administration of deuterium oxide (a treatment that result in a lengthening of the free-running period). As shifts in heat onset mirrored the free-running rhythm in locomotor activity, it became clear that the ovulatory cycle and locomotor rhythms are governed by a similar endogenous timing system (Fitzgerald and Zucker, 1976). Because estrous and activity onset were coupled temporally, it was suggested that the LH surge and locomotor activity are controlled by a single, endogenous oscillator, or a coupled, multioscillator system that regulates the rhythms of each process independently (Fitzgerald and Zucker, 1976). The former hypothesis postulated that the reproductive axis "tracks" four circadian cycles and ovulation occurs after the count is complete.

Converging lines of evidence over the next three decades established that both of these hypotheses are partially correct. We now know that the SCN provides a daily, stimulatory signal to the reproductive axis each day of the estrous cycle, closely preceding the active phase, in most spontaneously ovulating rodents (Legan and Karsch, 1975; Kriegsfeld and Silver, 2006), indicating that a single clock subserves both processes. However, this signal is only effective at stimulating the GnRH system to produce the LH surge in the presence of estradiol concentrations above a critical threshold. Prior to the day of proestrus, the developing ovarian follicles secrete insufficient estradiol to fulfill these criteria. The nature of the daily stimulatory signal from the SCN can be unmasked by implanting animals with estradiol capsules that result in proestrus concentrations of this hormone; in this case, daily LH surges occur (Legan and Karsch, 1975; Legan et al., 1975; Christian et al., 2005). Regarding the second hypothesis suggesting a multioscillator organization, although distinct clocks do not underlie locomotor rhythms and estrus, a hierarchical clock structure exists in which the SCN acts as the master pacemaker coordinating rhythmicity in subordinate oscillator systems of the reproductive axis, an arrangement discussed further below.

\section{CIRCADIAN NEUROCHEMICAL COMMUNICATION}

Whereas the same circadian pacemaker regulates locomotor and estrus onset, the communication modalities mediating each process likely differ. Transplants of fetal SCN tissue into bilaterally SCN-lesioned hamsters restores locomotor, but not endocrine, rhythms in the absence of neural outgrowth, suggesting that intact neural connections are required for endocrine rhythmicity whereas behavioral rhythms can be supported by a diffusible signal (Silver et al., 1990, 1996; Meyer-Bernstein et al., 1999). Confirmation of the importance of neural SCN communication in initiation of the GnRH/LH surge comes from studies using hamsters with "split" activity rhythms. When housed in constant light, some hamsters exhibit a splitting in behavior, with two daily activity bouts separated by $12 \mathrm{~h}$, each reflecting an antiphase oscillation of the left and right sides of the bilateral SCN (de la Iglesia et al., 2000; Tavakoli-Nezhad and Schwartz, 2005; Yan et al., 2005). Under these circumstances, ovariectomized (OVX) hamsters treated with estradiol exhibited two LH surges in a 24 -h period, each phase-locked to an individual activity bout (Swann and Turek, 1985).

The SCN sends pronounced, monosynaptic projections throughout the brain, including hypothalamic cell phenotypes driving reproductive function, principally ipsilaterally (DeVries et al., 1985; Watts and Swanson, 1987; van der Beek et al., 1997; Kriegsfeld et al., 2004). As a result, if a neural output signal from the SCN initiates the GnRH/LH surge, then one hemispheric set of $\mathrm{GnRH}$ neurons should be activated, ipsilateral to the activated SCN, with each locomotor activity bout. Conversely, if controlled by a diffusible signal, then the GnRH system should be activated concurrently on both sides of the brain, twice daily, $12 \mathrm{~h}$ apart. In a clever study by de la Iglesia et al. (2000) they found that each locomotor bout and LH surge is associated with unilateral activation of the GnRH system, ipsilateral to the activated SCN, confirming the importance of neural SCN communication to the GnRH system in ovulatory control. Both the GnRH system and several neurochemical systems upstream of the GnRH network receive SCN input and synergistically operate to precisely control the neuroendocrine events necessary to appropriately time ovulation and sexual motivation. 


\section{VASOACTIVE INTESTINAL POLYPEPTIDE}

Neurons synthesizing vasoactive intestinal polypeptide (VIP) are located in the retinorecipient, ventrolateral SCN "core" (Ibata et al., 1989; Tanaka et al., 1993; Moore et al., 2002), and represent potential output signals conveying circadian information to target effector systems. VIPergic SCN neurons project monsynaptically to GnRH neurons (van der Beek et al., 1997; Horvath et al., 1998) that express the VIP receptor $\mathrm{VPAC}_{2}$ (Smith et al., 2000). Several lines of evidence indicate an important role for this pathway in the timing of ovulation. First, GnRH neurons receiving VIPergic input preferentially express the neural activation marker, FOS, during the afternoon of the LH surge on the day of proestrus (van der Beek et al., 1994). Additionally, in vivo antisense antagonism of VIP production in the SCN abolishes GnRH/FOS activation in OVX + E2 primed female rats, suggesting the necessity of VIP output in triggering the afternoon $\mathrm{GnRH}$ surge (Harney et al., 1996; Gerhold et al., 2005). Furthermore, blocking the $\mathrm{VPAC}_{2}$ receptor attenuates $\mathrm{GnRH}$ neuronal cell firing during the afternoon surge in female, estradiol-treated mice (Christian and Moenter, 2008). The expression of VIP afferents on GnRH neurons is sexually dimorphic, with female rats exhibiting higher VIPergic innervation (Horvath et al., 1998), suggestive of a specific role for VIP in estrous cycle regulation. From a developmental standpoint, the number of VIP-GnRH contacts increases between prepubertal and adult female rats (Kriegsfeld et al., 2002), and VIP-innervated GnRH neurons exhibit lower activation levels in middle-aged female rats, suggesting that this SCN peptide may be partially responsible for the initiation of reproductive senescence in female rodents (Krajnak et al., 2001). Together, these lines of evidence suggest that direct VIP projections from the SCN to the GnRH system positively drive the GnRH/LH surge.

Gonadotropin-releasing hormone neurons do not express estrogen receptor $\alpha(\mathrm{ER} \alpha)$, the estrogen receptor subtype mediating the positive feedback effects of estradiol (Herbison and Theodosis, 1992b; Dorling et al., 2003; Wintermantel et al., 2006), pointing to additional neurochemicals and neural loci at which stimulatory circadian and estrogenic signals converge. As described below, the positive feedback effects of estradiol necessary for surge generation occur at intermediate target nuclei that express abundant ER $\alpha$. Several lines of evidence point to the anteroventral periventricular nucleus (AVPV) as an important site of circadian and estrogenic convergence necessary for initiating the GnRH/LH surge. The AVPV sends monosynaptic projections to GnRH cells, neurons in this region express FOS coincident with the LH surge, and lesions of the AVPV eliminate estrous cyclicity in both intact and ovariectomized, estradiol-treated rats (Wiegand et al., 1980; Wiegand and Terasawa, 1982; Ronnekleiv and Kelly, 1988; Gu and Simerly, 1997; Le et al., 1999). Moreover, the SCN sends pronounced monosynaptic projections to cells in the AVPV that express ER $\alpha$ (Herbison and Theodosis, 1992a,b; de la Iglesia et al., 1995; Watson et al., 1995; Shughrue et al., 1997). A multitude of neuropeptides and neurotransmitters are expressed within this relatively small nucleus, many of which express ER $\alpha$, including glutamate, GABA, galanin, dynorphin, enkephalin, substance $\mathrm{P}$, neurotensin, and kisspeptin and collectively represent potential sites for this convergence (reviewed in Herbison, 2008), with kisspeptin being the most well studied.
In addition to estrogen signaling in the AVPV, the SCN expresses estrogen receptors, providing the potential for direct actions on the master circadian pacemaker. In mice, a small proportion SCN cells express $\mathrm{ER} \alpha$, with a larger proportion expressing ER $\beta$ (Vida et al., 2008). In young female rats, ER $\beta$ mRNA exhibits a diurnal rhythm in the SCN that is dependent on estradiol concentrations, suggesting that the impact of estrogen on the SCN may be gated through time- and estradiol-dependent receptor turnover (Wilson et al., 2002; Shima et al., 2003). In human SCN, both ER $\alpha$ and ER $\beta$ are expressed (Kruijver and Swaab, 2002). In addition to direct actions on the SCN, estrogen may act indirectly to regulate circadian functioning; $\mathrm{ER} \alpha$-expressing cells in the preoptic area project to the SCN in female Syrian hamsters, providing an additional means of estrogen and circadian integration (de la Iglesia et al., 1999). The specific role of both direct and indirect estrogenic signaling to SCN in the preovulatory LH surge remains unspecified and represents an exciting opportunity for further investigation.

\section{VASOPRESSIN}

Vasopressinergic (AVPergic) cells in the dorsomedial SCN target ER $\alpha$ - expressing cells in the AVPV (Hoorneman and Buijs, 1982; DeVries et al., 1985; de la Iglesia et al., 1995; Watson et al., 1995), and AVP injections produce surge-like LH levels in SCN-lesioned, ovariectomized (OVX), estradiol-treated rats (Palm et al., 1999). Likewise, cells in this brain region express the vasopressin receptor, V1 $1_{a}$ (Ostrowski et al., 1994; Funabashi et al., 2000a). The convergence of circadian output signals and estradiol feedback within the AVPV has generated much interest in this nucleus as the integration site of these dual signals in the regulation of the GnRH surge. Indeed, anti-estrogens targeting the AVPV inhibit the LH surge in ovariectomized, estradiol-treated rats (Petersen and Barraclough, 1989).

Vasopressin gene transcription in the SCN is directly controlled by the molecular clockwork at the cellular level (Grace et al., 1999; Munoz et al., 2002) and is released in a circadian manner (Shinohara et al., 1994), with a peak coinciding with the onset of the LH surge (Schwartz et al., 1983; Kalsbeek et al., 1995). AVP, but not VIP, release is synchronous with GnRH secretion in co-cultures of medial preoptic area (mPOA) and SCN brains slices (Funabashi et al., 2000b), suggesting vasopressin may act as a circadian stimulator of GnRH. Furthermore, AVP injections directed at the mPOA produce surge-like LH levels in SCN-lesioned, ovariectomized, estradiol-treated rats (Palm et al., 1999). By contrast, central AVP receptor antagonists attenuate the LH surge in proestrus rats (Funabashi et al., 1999). Finally, the inability of clock mutant mice to generate an LH surge is associated with diminished AVP mRNA expression in the SCN, a phenotype that can be restored via central injections of AVP, further linking this peptide to the circadian control of ovulation (Miller et al., 2004). Importantly, central injections of AVP are only capable of inducing a surge-like pattern of GnRH secretion during a narrow time window in the afternoon (Palm et al., 2001b), suggesting additional temporal control at SCN target loci, a concept described further below.

\section{RFAMIDE PEPTIDES: KISSPEPTIN AND GnIH}

Despite the established role of the circadian clock and estradiol in the regulation of GnRH secretion and, ultimately, ovulation, the 
specific targets of these requisite signals are less well understood. As described previously, the AVPV represents an important integration site for the positive feedback effects of estrogen and circadian signaling. Conversely, the neurochemical substrates and target loci at which circadian and estrogenic signals converge to maintain $\mathrm{LH}$ at low concentrations throughout the majority of the estrous cycle (i.e., negative feedback), and the mechanisms that suppress negative feedback at the time of the LH surge, remained unspecified. Converging lines of evidence from a number of reports point to two potent, reproductively relevant neuropeptides in the RFamide (Arg-Phe- $\mathrm{NH}_{2}$ ) family, gonadotropin-inhibitory hormone (also known as RFamide-related peptide-3) and kisspeptin, in mediating circadian controlled estradiol negative and positive feedback, respectively (reviewed in Khan and Kauffman, 2011).

\section{Kisspeptin}

The discovery of kisspeptin has markedly impacted the field of reproductive biology since its initial isolation in human placenta and its recognition as the endogenous ligand for the orphan Gprotein coupled receptor, GPR54 (Kotani et al., 2001; Muir et al., 2001; Ohtaki et al., 2001). Kisspeptin was initially characterized as a tumor metastasis suppressor sequence and originally named metastin (Lee et al., 1996). The Hershey, Pennsylvania group credited for this discovery shortened the name of the gene encoding the metastin peptide to KiSS1, reflecting its suppressor sequence "SS," while "Ki" was added to pay homage to an earlier discovery in the same town, the Hershey's Kiss (Lee et al., 1996). KiSS1-GPR54 signaling was discovered to play a critical role in reproductive physiology in 2003 when two groups reported that mutation of the GPR54 receptor results in idiopathic hypophysiotropic hypogonadism in humans with an identical phenotype observed in mice with a targeted deletion in this receptor (de Roux et al., 2003; Funes et al., 2003; Seminara et al., 2003). Since these initial discoveries, numerous contributions by researchers working at varying levels of analysis indicate that kisspeptins are critical regulators of sexual differentiation and maturation as well as normal, adult reproductive functioning across mammalian species, including humans (de Roux et al., 2003; Funes et al., 2003; Seminara et al., 2003; Keen et al., 2008; Kauffman, 2009; Roseweir et al., 2009; Lehman et al., 2010a,b; Pineda et al., 2010a,b; Luque et al., 2011; Mayer and Boehm, 2011).

The KiSS1 gene encodes a family of neuropeptides, kisspeptins, that act as pronounced stimulatory regulators of the GnRH system. The initial product is a 145 amino acid propeptide, kisspeptin-145, that is cleaved into the active 54 amino acid peptide, kisspeptin54. Three shorter products, kisspeptin 10, 13, and 14 result from further cleavage of the 54 amino acid sequence; all are biologically active, bind with similar affinity to GPR54, and share an RFamide sequence on their C termini (Kotani et al., 2001; Muir et al., 2001). In rodents, KiSS1 mRNA expressing cells are localized to the AVPV and arcuate (ARC) nuclei, with populations exhibiting a high percentage of ER $\alpha$-expressing cells (Gottsch et al., 2004; Smith et al., 2005b; Clarkson and Herbison, 2006; Revel et al., 2006; Greives et al., 2007). The effects of estradiol on kisspeptin activity, however, varies by nucleus, with ovariectomy decreasing KiSS1 mRNA in the AVPV and increasing KiSS1 expression in the ARC, pointing to a role for kisspeptin in estradiol positive and negative feedback, respectively (Smith et al., 2005a,b). Analogous findings are seen in males, with castration increasing KISS1 expression in the ARC and decreasing expression in the AVPV (Smith et al., 2005a,b; Kauffman, 2010). These effects are likely regulated both through direct actions of testosterone/dihydrotestosterone on androgen-responsive kisspeptin neurons and through aromatization of testosterone to estradiol, as kisspeptin neurons express both receptors and respond predictably to both sex steroids (Smith et al., 2005b). Exogenous kisspeptin administration potently induces $\mathrm{LH}$ release as well as upregulates FOS expression in GnRH neurons (Gottsch et al., 2004; Irwig et al., 2004; Matsui et al., 2004; Navarro et al., 2005a,b). In addition to direct actions of AVPV kisspeptin neurons on GnRH cells (Irwig et al., 2004; Han et al., 2005; Kinoshita et al., 2005; Clarkson and Herbison, 2006; Smith et al., 2008), there is some evidence that ARC kisspeptin cells may regulate the release of $\mathrm{GnRH}$ via direct actions on $\mathrm{GnRH}$ terminals (d'Anglemont de Tassigny et al., 2008). In one recent study, genetic ablation of kisspeptin cells or cells expressing GPR54 throughout development did not impact female pubertal development and the animals were fertile, although loss of GPR54-expressing cells resulted in blunted $\mathrm{LH}$, reduced ovarian weights, and irregular estrous cycling (Mayer and Boehm, 2011). In adult animals, acute ablation of kisspeptin neurons markedly disrupted fertility and estrous cyclicity, whereas removal of 93\% of GPR54-expressing GnRH cells resulted in more mild reductions in LH, fertility, and estrous cycling (Mayer and Boehm, 2011). Together, these findings suggest that kisspeptin signaling is required for adult female reproductive functioning and compensatory mechanisms can overcome the necessity for kisspeptin when this gene is inactivated throughout development. Given that as few as three GnRH neurons are sufficient to support activity of the hypothalamopituitary-gonadal (HPG) axis (Silverman et al., 1985; Gibson et al., 1988), it is unclear whether GPR54-expressing GnRH neurons can be dispensed within LH surge control.

As mentioned previously, the observation across rodent species that the SCN projects to the AVPV and this brain region is essential for production of the LH surge, combined with the knowledge that AVPV kisspeptin cells respond positively to estradiol, made these cells an attractive target of exploration in the initiation of GnRH/LH surge. KiSS1 cells in the AVPV express FOS at the time of the LH surge in naturally cycling, ovariectomized, estradioltreated rats (Smith et al., 2006; Adachi et al., 2007). This circadian pattern of expression persists in constant darkness (Robertson et al., 2009), suggesting endogenous circadian regulation of this cell population rather than reliance on external temporal cues. In mice, this daily pattern of KiSS1 expression, and KiSS1 cells expressing $c$-fos, is abolished by ovariectomy, and reinstated following steady-state estradiol replacement (Robertson et al., 2009), pointing to a permissive role for estradiol in the circadian control of KiSS1 in this species.

These results point to either an endogenous, self-sustained rhythm in kisspeptin neurons, circadian control through upstream projections from the SCN, or a combination of both mechanisms of control. We examined both of these possibilities using Syrian hamsters. Consistent with findings in mice, FOS expression in kisspeptin immunoreactive (ir) cells expressed a daily rhythm in ovariectomized, estradiol-treated hamster, with peak 
co-expression concomitant with the timing of the LH surge. In contrast to results observed in mice, ovariectomy results in a blunted rhythm of kisspeptin-FOS co-expression, but not its abolition (Williams et al., 2011). These latter findings point to potential species differences in the role estrogen plays in AVPV kisspeptin regulation and/or post-transcriptional modification of the KiSS1 gene, resulting in differences in cells visualized with mRNA versus protein analyses. To determine whether the SCN projects to kisspeptin cells to mediate these observed rhythms, we examined projections from VIPergic and AVPergic SCN cells, given the role of these neuropeptides in positively driving the LH surge. We found that AVPergic SCN cells project directly to a majority of kisspeptin-ir cells, whereas VIPergic SCN cells did not (Figure 1). These results are consistent with previous findings in mice (with synapses confirmed at the electron microscopy level), with estrogen increasing the percent of $\mathrm{GnRH}$ cells with AVPergic terminal appositions (Vida et al., 2010).

Previous findings indicate that that administration of AVP can only induce the preovulatory LH surge within a narrow time window in rats (Palm et al., 2001b), suggesting a gated mechanism of control at SCN target loci. The gating of SCN information flow may be controlled within kisspeptin cells in the AVPV, at the level of GnRH neurons, or a combination of both mechanisms. To select among these possibilities, we examined whether: (1) kisspeptin cells within the AVPV respond in a time-dependent manner to AVP stimulation, and (2) if GnRH neurons display time-dependent sensitivity to kisspeptin signaling. If time-dependent sensitivity is controlled at the level of the AVPV, then one would expect kisspeptin cells to exhibit daily changes in sensitivity to AVP stimulation and contain an endogenous time-keeping mechanism. Alternatively, if the gating of control occurs within GnRH cells, then one would expect the GnRH system to display daily sensitivity in response to both AVP and kisspeptin administration. Our findings indicate that the kisspeptin system responds indiscriminately to AVP administration, regardless of time of day, whereas the $\mathrm{GnRH}$ system is only sensitive to kisspeptin stimulation at the time that the surge would normally occur (Williams et al., 2011). These results further support the notion that kisspeptin cells do not keep circadian time but, instead, their activity is driven by AVPergic SCN cells. However, these findings point to an important role for autonomous circadian oscillators in GnRH cells underlying time-dependent sensitivity to upstream signaling. Alternatively, it is possible that the master clock in the SCN communicates timing information to GnRH cells that do not maintain the capacity for endogenous rhythmicity. Given that SCN-derived VIPergic cells project monosynaptically to GnRH neurons, this cell phenotype represents an ideal candidate to communicate such timing information. Finally, a combination of both mechanisms may underlie such daily changes in GnRH cell sensitivity, with VIPergic SCN
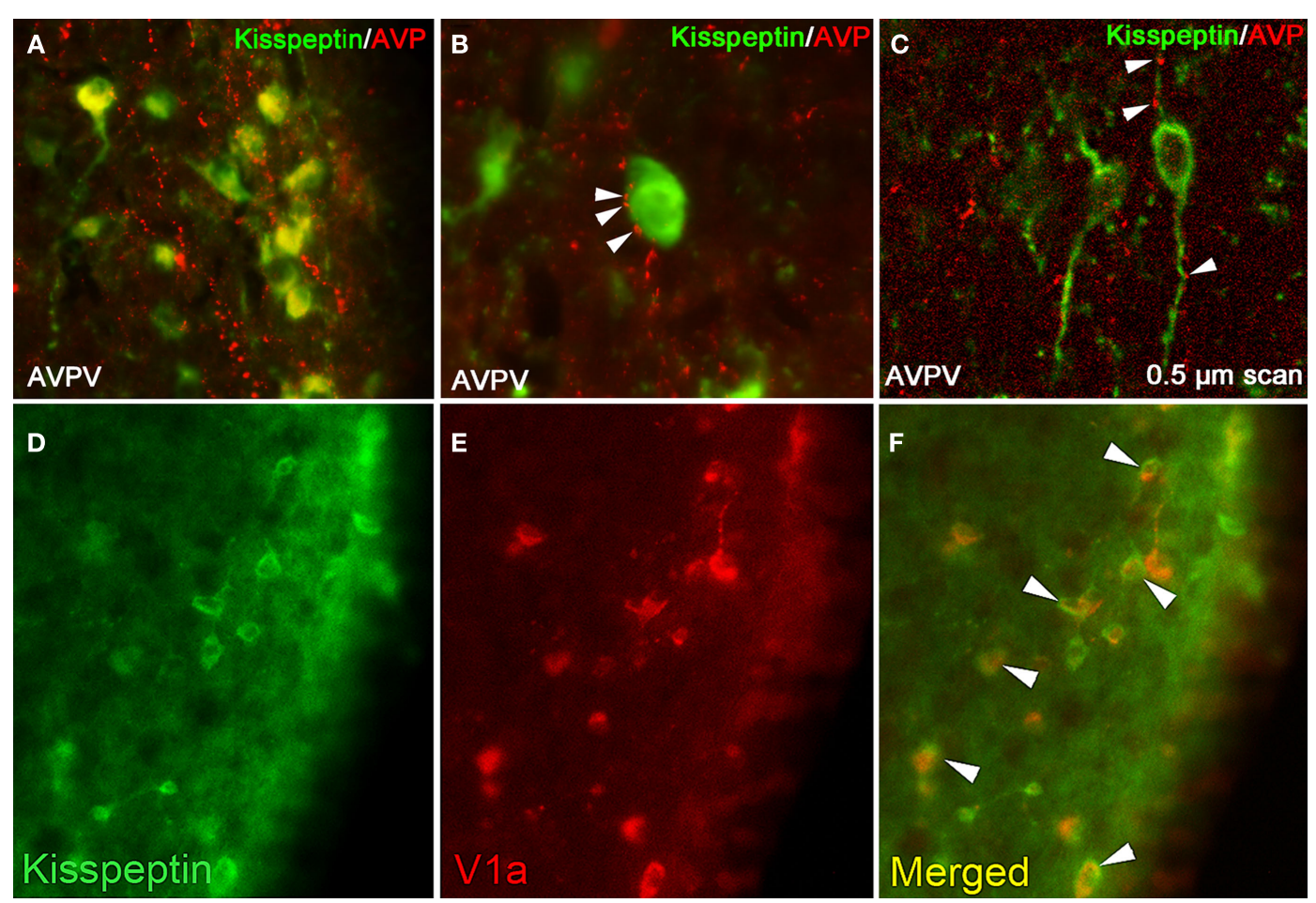

FIGURE 1 | Kisspeptin-ir cells in the hamster AVPV receive SCN-derived fiber contacts expressing AVP-ir. (A) Low-power photomicrographs of AVP-ir in the AVPV, in which kisspeptin cell bodies receive extensive AVP-ir fiber contacts. (B) High power photomicrograph showing several presumptive AVP-ir terminal boutons on a kisspeptin-ir cell body at the light level. (C) Confocal image $(0.5 \mu \mathrm{m}$ scan taken at $\times 400)$ confirming AVP-ir contacts upon kisspeptin-ir cell body and processes. In (B,C), Arrows are indicative of close contacts. (D-F) Kisspeptin cells in the AVPV express the $\mathrm{V} 1$ a receptor. (D) Low-power photomicrographs of kisspeptin-ir cells in the AVPV, (E) V1a-ir cells in the AVPV, and (F) the merged image showing overlap between kisspeptin-ir and $\mathrm{V} 1 \mathrm{a}$-ir. Modified from Williams et al. (2011). 
communication synchronizing independent GnRH cellular oscillators to coordinate the timing in their responsiveness to upstream signaling.

At the cellular level, circadian rhythms are generated by $24-\mathrm{h}$ autoregulatory transcriptional/translational feedback loops consisting of "clock" genes and their protein products (Figure 2; Reppert and Weaver, 2002; Maywood et al., 2007; Chen et al., 2009; Mohawk and Takahashi, 2011). In mammals, the feedback loop begins in the cell nucleus where CLOCK and BMAL1 proteins heterodimerize and drive the transcription of the Period (Per1, Per2, and Per3) and Cryptochrome (Cry1 and Cry2) genes by binding to the E-box (CACGTG) domain on their gene promoters. Once translated, PER and CRY proteins build in the cytoplasm of the cell over the course of the day, and inevitably form hetero- and homodimers that feed back to the cell nucleus to inhibit CLOCK:BMAL1 mediated transcription. The timing of nuclear entry is balanced by regulatory kinases that phosphorylate the PER and CRY proteins, leading to their degradation (Lowrey et al., 2000; Wang et al., 2007; Mohawk and Takahashi, 2011). Two other promoter elements, DBP/E4BP4 binding elements ( $\mathrm{D}$ boxes) and REV-ERB $\alpha /$ ROR binding elements (RREs; Ueda et al., 2005), also participate in cellular clock function. REV-ERB $\alpha$, an orphan nuclear receptor, negatively regulates the activity of the CLOCK:BMAL1. The same mechanism controlling Per and Cry gene transcription also controls transcription of REV-ERB $\alpha$. Similarly, the transcription factor DPB is positively regulated by the CLOCK:BMAL1 complex (Ripperger and Schibler, 2006) and acts as an important output mechanism, driving rhythmic transcription of other output genes via a PAR basic leucine zipper (PAR bZIP; Lavery et al., 1999).

Clock genes are expressed in the SCN, but also widely distributed throughout other brain regions and peripheral tissues. GnRH cells express the same clock genes that drive circadian rhythms at the cellular level in the SCN, both in vitro (Chappell et al., 2003; Zhao and Kriegsfeld, 2009) and in vivo (Olcese et al., 2003; Hickok and Tischkau, 2010; Matagne et al., 2012). Importantly, mice bearing a mutation in the essential circadian clock gene, Clock, display abnormal estrous cycles and abnormal LH surge induction in response AVP administration (Miller et al., 2004), suggesting an important role for clock genes (potentially in GnRH cells) in normal estrous cycling and ovulation. Consistent with our findings in vivo, immortalized $\mathrm{GnRH}$ neurons (i.e., GT1-7 cells) exhibit $\sim 24$ h changes in sensitivity to kisspeptin and VIP signaling (Zhao and Kriegsfeld, 2009). These findings suggest that an endogenous timing mechanism in $\mathrm{GnRH}$ cells gates daily changes in responsiveness to upstream, stimulatory neurochemicals. More recently, Chappell and colleagues found that estrogen-treated GT1-7 cells exhibit a rhythm in GPR54 expression that is abolished in the absence of estrogen (Tonsfeldt et al., 2011). These results are intriguing given the absence of $\mathrm{ER} \alpha$ in this cell population, suggesting participation of ER $\beta$ in this rhythm of GRP54 transcription. Whether GnRH neurons gate responsiveness to all upstream signals, only stimulatory input, or only those mediators regulating the LH surge remains an exciting opportunity for further inquiry. Likewise, given that all functional studies have been conducted in vitro, these findings should be interpreted

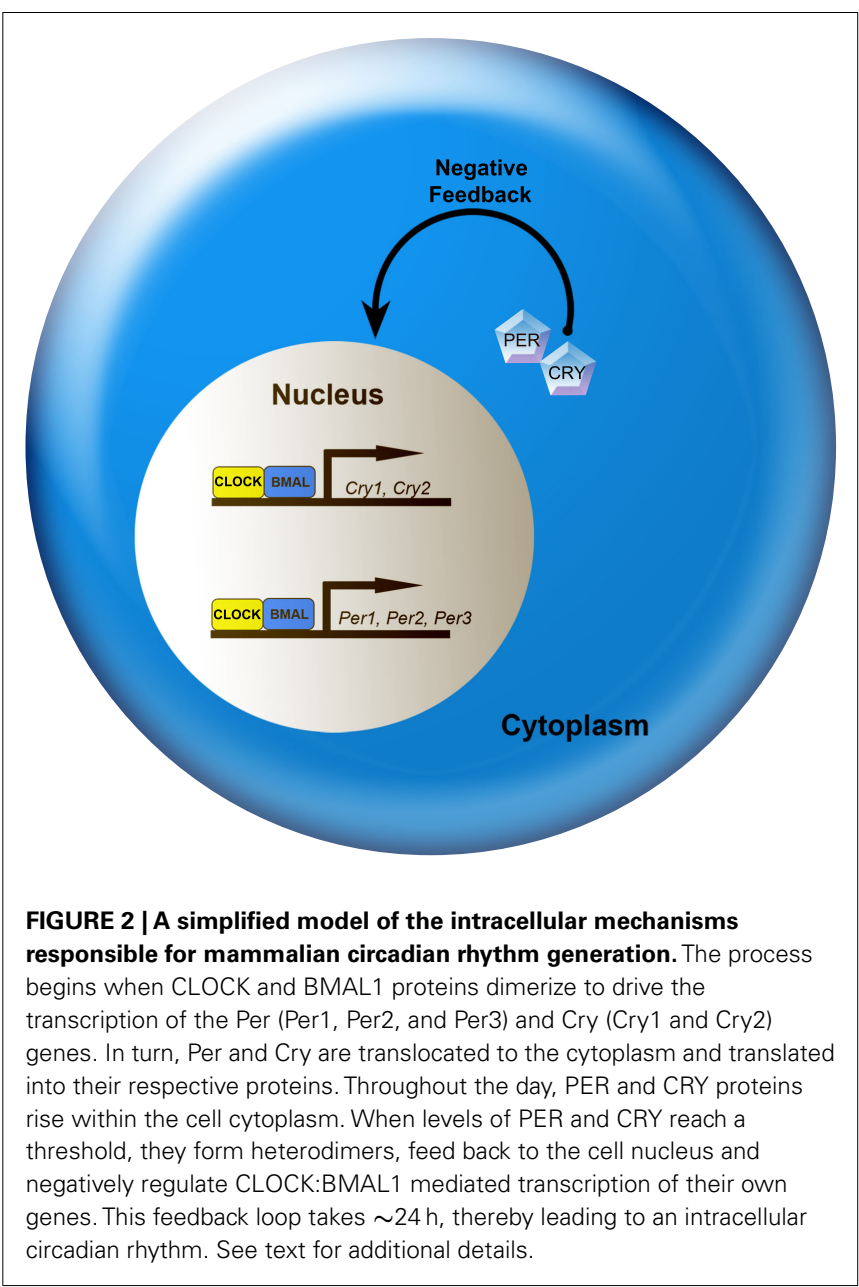

cautiously as the immortalization process may lead to alterations in GnRH cellular functioning different from those in vivo.

\section{Gonadotropin-inhibitory hormone}

Tsutsui et al. (2000) isolated a dodecapeptide, SIKPSAYLPLRFamide, from Japanese quail brain. Neurons for this neuropeptide were concentrated in the paraventricular nucleus of the hypothalamus, with projections to the hypophyseal portal system, suggesting a role in anterior pituitary regulation. Using cultured quail pituitaries, Tsutsui and colleagues discovered a dose-dependent inhibition of gonadotropin release following administration of this novel peptide. Because this peptide directly inhibited gonadotropin release, they named it gonadotropin-inhibitory hormone, or $\mathrm{GnIH}$ (Tsutsui et al., 2000). Following this initial discovery, we examined the functional significance of $\mathrm{GnIH}$ in mammals, establishing this neuropeptide as robust inhibitor of the reproductive axis in Syrian hamsters, with identical expression patterns in mice and rats (Kriegsfeld et al., 2006). Since this initial characterization, it has become clear that $\mathrm{GnIH}$ acts as a pronounced negative regulator of HPG axis activity in all species investigated, including hamsters, mice, rats, cattle, sheep, non-human primates, and humans (reviewed in Bentley et al., 2010; Kriegsfeld et al., 2010; Smith and Clarke, 2010; Tsutsui et al., 2010). 
In rats, hamsters and mice, GnIH neuronal cell bodies are tightly localized to the dorsomedial hypothalamus (DMH) and project directly to the POA, forming close appositions to $\mathrm{GnRH}$ cells (Kriegsfeld et al., 2006; Johnson et al., 2007), suggesting the potential for direct, neural regulation of the GnRH network. Administration of GnIH rapidly suppresses LH release in all mammalian species investigated to date (reviewed in Bentley et al., 2010; Kriegsfeld et al., 2010; Tsutsui et al., 2010). Direct application of $\mathrm{GnIH}$ to $\mathrm{GnRH}$ cells in brains slices from male and female mice decreased neural activity in a subset of cells (Ducret et al., 2009), supporting a suppressive role for this peptide via direct actions on GnRH neurons. Furthermore, electrophysiological recordings suggest a direct postsynaptic inhibition of $\mathrm{GnRH}$ cell firing may occur via GnIH-mediated hyperpolarization of potassium $(\mathrm{K}+)$ channels in vGluT2-GnRH neurons (Wu et al., 2009).

In addition to the direct action on GnRH, the actions of $\mathrm{GnIH}$ on pituitary gonadotropes remain more controversial. Suggestive evidence for this possibility comes from studies showing that the GnIH receptor (GPR147; Yin et al., 2005) is localized to rat and Syrian hamster pituitaries (Hinuma et al., 2000; Gibson et al., 2008), and GnIH-ir fibers have been reported to extend into the external layer of the median eminence (Gibson et al., 2008). Additionally, recent studies in which peripheral, but not central, injections of $\mathrm{GnIH}$ inhibits $\mathrm{GnRH}$-elicited $\mathrm{LH}$ release, suggesting actions at the pituitary level (Murakami et al., 2008). In one study in rats, peripheral injections of the retrograde tracer, Fluorogold (FG), label sparse numbers of GnIH cells, suggesting that these cells do not contact the pituitary portal system (Rizwan et al., 2009). Despite showing few GnIH cells labeled with FG, intravenously administered $\mathrm{GnIH}$ rapidly (within $5 \mathrm{~min}$ ) inhibited GnRH-induced LH release in the same study (Rizwan et al., 2009). These data indicate the potential for GnIH to act on pituitary gonadotropes or suggest that intravenously delivered $\mathrm{GnIH}$ crosses the blood-brain barrier to impact GnRH cell bodies or terminals. Whether or not endogenous GnIH acts on the pituitary in addition to $\mathrm{GnRH}$ cells in mammalian species requires further investigation to clarify whether discrepant findings represent interspecific differences or result from technical variation across studies.

Given the pronounced inhibitory actions of GnIH in the mammalian brain, we examined the possibility that this peptide participates in mediating the negative feedback effects of estradiol. Treatment of female rats with GnIH results in marked inhibition of GnRH neuronal activity at the time of the LH surge, providing support for this possibility (Anderson et al., 2009). In Syrian hamsters, we found that GnIH-ir cells express ER $\alpha$ and respond to acute estradiol treatment with increased FOS expression, suggesting activation by gonadal steroids (Kriegsfeld et al., 2006). Contrasting results were observed in one recent report, with treatment of mice with estrogen for 4 days leading to a decrease in GnIH mRNA expression (Molnar et al., 2011). The discrepancy in the impact of estrogen in mice and hamster may result from the timing at which the brains were collected for analysis - hamster brains were collected prior to the LH surge when negative feedback effects of estradiol are maximal, whereas when in the day mouse brains were sampled was not reported.
We next explored whether GnIH neurons might be a locus of integration for steroidal and circadian signals, providing a mechanism to coordinate the removal of estradiol negative feedback with SCN-mediated stimulation of the GnRH/LH surge (Figure 3). First, we examined the pattern of GnIH cellular activity, uncovering a daily pattern with trough activity at the time of the LH surge, suggesting the removal of negative feedback at this time (Gibson et al., 2008). Additionally, using anterograde tract tracing, we found that the SCN projects to a large proportion of $\mathrm{GnIH}$ cells, providing a mechanism for timing removal of negative drive on the GnRH system. Finally, by exploiting the "splitting" phenomenon seen in hamsters housed in LL described previously, we found that activation of the GnIH system is asymmetrical. Importantly, this asymmetry is opposite to that seen for the GnRH system, suggesting that the SCN concomitantly activates ipsilateral GnRH cells at the same time as removing the suppressive influence of $\mathrm{GnIH}$ on the same side of the brain (Figure 3; Gibson et al., 2008).

Recently, a meticulously comprehensive series of studies by Pineda et al. investigated the role of GnIH using a selective antagonist (RF9) of GnIH and a related peptide in the same family, neuropeptide FF (NPFF). Alterations in NPFF and interactions with its receptor do not alter gonadotrophin secretion (Pineda and Tena-Sempere, unpublished observations), suggesting that the effects of RF9 are likely mediated through blockade of the actions of RFRP-3 (Pineda et al., 2010b). The role of RF9 was investigated in male and female mice and rats. Injections of RF9 to cycling females led to a rapid and sustained, dose-dependent increase in LH both during estrus and diestrus, supporting a role for $\mathrm{GnIH}$ in maintaining low $\mathrm{LH}$ concentration through negative feedback. Analogous results were seen in males, with RF9 leading to a rapid and prolonged increase in $\mathrm{LH}$ and FSH. Together, these findings and those for kisspeptin, point to an important role for these opposing RFamide neuropeptides in the integration of positive and negative effects of estradiol with circadian signaling in the generation of the GnRH/LH surge.

It is likely that other neural loci upstream of the GnRH system are targets of the SCN involved in the timing of the LH surge. Dualphenotype neurons expressing GABA/glutamate within the AVPV, for example, have been implicated in the control of GnRH activity and are regulated by estradiol feedback (Leranth et al., 1985; Jarry et al., 1995; Christian et al., 2009). GnRH neurons express AMPA, NMDA, GABA A and GABA B receptors (Gore et al., 1996; Spergel et al., 1999; Sullivan and Moenter, 2004; Sliwowska et al., 2006) and blockade of glutamatergic receptors prevents the LH surge in rats (Lopez et al., 1990; Brann and Mahesh, 1991). GnRH neurons respond to GABA and glutamate differentially across the day in female mice, with inhibitory responses in the morning during estrogen negative feedback and excitatory responses in the afternoon during estrogen positive feedback (Petersen et al., 2003; Christian and Moenter, 2007). Additionally, the number of AVPVoriginating synaptic contacts onto $\mathrm{GnRH}$ neurons that express both GABA and glutamatergic vesicular transporters increases around the time of the LH surge (Ottem et al., 2004). Furthermore, these synaptic contacts are estradiol-sensitive, suggesting the coupling of circadian and estrogenic input mediates GABA/glutamate signaling to GnRH neurons (Ottem et al., 2004). Though no direct connections have been reported between the SCN and 


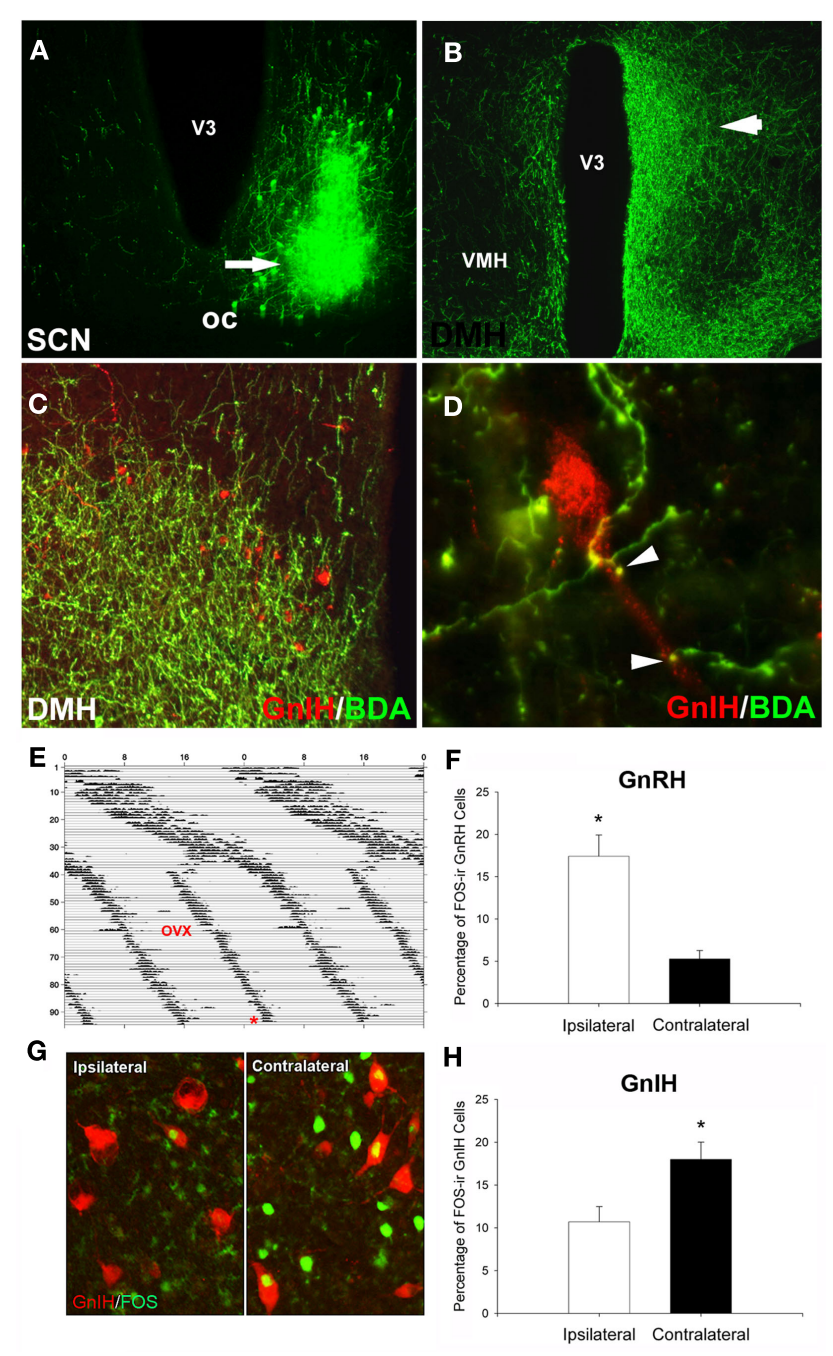

FIGURE 3 | Suprachiasmatic nucleus fibers project to GnIH-ir cells in the DMH. (A) Example injection site from an injection of biotinylated dextran amine (BDA) that filled the ventrolateral aspect of the SCN; (B) low-power photomicrograph indicating terminal fibers from the SCN project to the $\mathrm{DMH}$, principally ipsilaterally. (C,D) Examples of SCN projections in close apposition to $\mathrm{GnlH}$-ir cells in the $\mathrm{DMH}$ at the light level [(C), low-power; (D), high power]. (E-H) Lateralization of $\mathrm{GnRH}$ and $\mathrm{GnIH}$ activation in split hamsters. The pattern of SCN activation is lateralized in animals exhibiting two daily bouts of activity. $\mathrm{GnIH}$ cellular activity is lateralized and opposite to that of $\mathrm{GnRH}$, indicating $\mathrm{SCN}$-mediated removal of $\mathrm{GnlH}$ inhibition at the time of the LH surge. (E) Actogram of wheel-running activity in estradiol-implanted, ovariectomized (OVX) hamsters kept in constant light conditions (LL) from Day 1 onward (days indicated by $y$ axis, hours by $x$ axis). Split hamsters were killed $\left(^{*}\right) 1 \mathrm{~h}$ before the onset of one of the two activity bouts. (G) Photomicrograph of FOS activation in $\mathrm{GnlH}$ cells of split hamsters, showing ipsilaterally reduced $\mathrm{GnIH}$ activation when $\mathrm{SCN}$ and $\mathrm{GnRH}$ activation are high. Mean $\pm \mathrm{SEM}$ ) percentage of FOS-ir (F) GnRH and (H) GnlH cells in split hamsters. * Significantly different from the opposite hemisphere's activational state, $P<0.05$. Modified from Gibson et al. (2008).

GABA/glutamate neurons within the AVPV, the expression of V1a receptors in GABA neurons within this nucleus (Kalamatianos et al., 2004) provides a potential SCN-mediated mechanism of control. It is possible that circadian input to this neuronal population comes indirectly through kisspeptin signaling; kisspeptin upregulates GABA transmission in the AVPV during estradiol negative (but not positive) feedback, suggesting local signaling within this nucleus (Pielecka-Fortuna and Moenter, 2010).

\section{CIRCADIAN CONTROL OF PREGNANCY}

In addition to the circadian control of ovulation, multiple lines of evidence indicate a critical role of the SCN in the regulation of prolactin (PRL) secretion and pregnancy maintenance. The release of prolactin, an adenohypophysis-derived hormone with myriad functions, most notably in lactation and pregnancy maintenance, is controlled by a balance of inhibitory and releasing factors. The circadian control of prolactin is abundantly clear, with a proestrus surge of PRL release occurring in the late afternoon. Additionally, ovariectomized rats treated with estradiol exhibit daily PRL surges around the time of the LH surge (Pan and Gala, 1985). Furthermore, as with the regulation of luteinizing hormone, ovariectomized, and estradiol-treated rats fail to exhibit a PRL surge following SCN lesions, suggesting a necessary role of the SCN in the release of PRL, either directly or indirectly (Pan and Gala, 1985).

Stimulation of the cervix during mating initiates twice daily prolactin surges, consisting of a diurnal, and nocturnal surge that maintains the corpora lutea and thus the secretion of progesterone, facilitating pregnancy maintenance. Evidence for the circadian regulation of the prolactin surge comes from studies similar to those linking the central clock to ovulation. The PRL surge is entrained to the light cycle and free-runs in constant conditions (Bethea and Neill, 1979; Yogev and Terkel, 1980), and SCN lesions prevent the mating-induced prolactin surges (Kawakami et al., 1980) underscoring the endogenous, circadian control of this phenomenon. Furthermore, pharmacological knockdown of the core SCN clock genes disrupts the PRL surge in rats (Poletini et al., 2007) suggesting a link between the molecular clock and the circadian drive of prolactin. Given the function of PRL in corpora lutea maintenance, disruptions in the circadian control of PRL may prevent the rise in corpora lutea-derived progesterone secretion and thus lead to an increased rate of abortion or fetal reabsorption (Milligan and Finn, 1997; Miller et al., 2004).

The SCN regulates secretory patterns of PRL regulators, including the primary PRL-inhibiting factor, dopamine (DA) and PRLstimulating factor, oxytocin (Freeman et al., 2000). SCN-derived VIP is a likely regulatory factor in both cases, as VIPergic fibers project to dopaminergic neurons in the ARC and paraventricular nuclei (PVN; Teclemariam-Mesbah et al., 1997; Gerhold et al., 2001) and to oxytocin-secreting cells in the PVN (TeclemariamMesbah et al., 1997); areas considered to be critical for PRL regulation. DA cells in the ARC and cells in the PVN co-express the core circadian clock gene, Per1, suggesting a role for autonomous clocks operating in these cell types in mediating rhythms in PRL secretion (Kriegsfeld et al., 2003; Sellix et al., 2006). Furthermore, the rhythm of VIP in the paraventricular nucleus, where PRLstimulating oxytocin neurons reside, is phase-locked to the rhythm of PRL, suggesting that this peptide may link the SCN to this regulatory system (Egli et al., 2004). Both DA and OXY neurons within the PVN express the VIP receptor, VPAC 2 (Gerhold et al., 2001; Egli et al., 2004), providing a mechanism of control between 


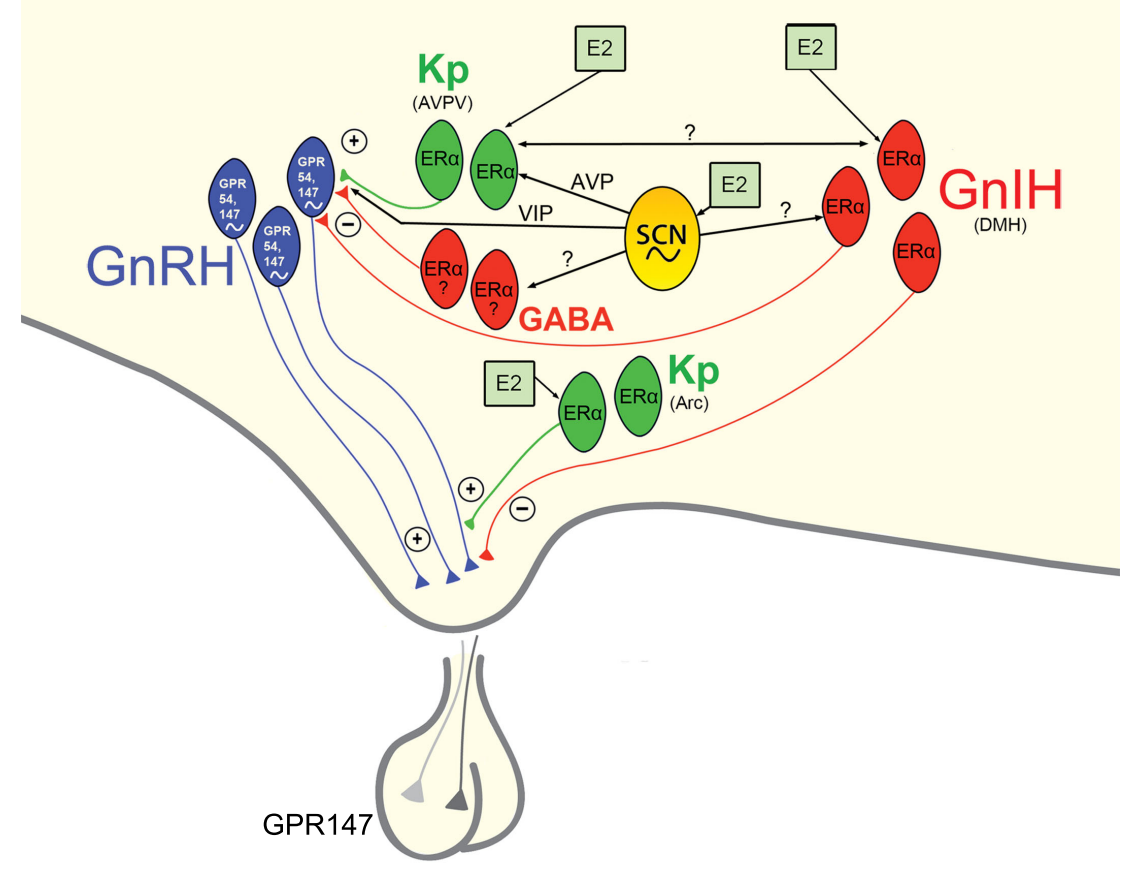

FIGURE 4 | Proposed model of circadian initiation of the preovulatory LH surge in spontaneously ovulating rodents by major positive and negative regulators of $\mathbf{G n R H}$ neuronal activity. Black lines depict monosynaptic projections from the SCN to $\mathrm{GnRH}$ neurons and to major positive (kisspeptin, Kp) and negative (GnIH, GABA) neurochemical mediators of the $\mathrm{GnRH}$ system that contain estrogen receptors. Kisspeptin cells in the AVPV are active at the time of the LH surge. Neurons containing $E R \alpha$ in the preoptic area and elsewhere are known to project to the SCN and to the vicinity of $\mathrm{GnRH}$ neurons and may play a role in mediating the circadian signal to $\mathrm{GnRH}$ neurons directly and/or indirectly. Whereas estrogen-responsive cells have not been definitively shown to project specifically to $\mathrm{GnRH}$ neurons, the emergence and sexual dimorphism of kisspeptin cells and fibers that project to $\mathrm{GnRH}$ cell bodies provide compelling evidence for the direct connection between these two neural phenotypes. Connections between the $\mathrm{GnIH}$ and $\mathrm{GnRH}$ systems indicate a putative role for $\mathrm{GnIH}$ in modulating the negative feedback effects of estrogen with SCN communication allowing for removal of negative feedback on the reproductive axis during the time of the $\mathrm{LH}$ surge. A similar role for SCN-GABA interactions is likely, although projections SCN projections and ER $\alpha$ expression specific to AVPV GABAergic cells have not been empirically examined. Kisspeptin cells in the ARC likely serve to modify $\mathrm{GnRH}$ output at the level of the terminal. See text for additional details. the master clock and PRL regulatory neurons. Additionally, VIP antagonists directed at the SCN prevent the decrease in PVN DA, and eliminate the afternoon PRL surge in female rats (Harney et al., 1996). Finally, antisense oligonucleotide knockdown of clock genes within the SCN eliminates mating-induced PRL secretion (Poletini et al., 2007). Together, these results suggest a critical role for the circadian system in PRL regulation through VIPergic SCN communication to OXY and DA neurons, with possible additional contributions by autonomous clocks in these regulatory neuronal populations.

The circadian regulation of PRL secretion has important functional implications for female reproductive success. Female mice expressing a null mutation in the Clock gene exhibit disrupted ovulatory cyclicity, as well as a high incidence of pregnancy interruption (Miller et al., 2004). Spontaneous abortions and fetal reabsorption rates in these mice stem from insufficient PRL release during the initial stages of pregnancy, thus leading to blunted progesterone levels and insufficient support for the corpora lutea (Miller et al., 2004). The connections between the SCN and PRL release, and regulation of the $\mathrm{Prl}$ gene promoter by the core molecular clockwork via a non-canonical E-Box (Palm et al., 2001a; Poletini et al., 2010; Guillaumond et al., 2011), point to a direct link between the circadian system and pregnancy maintenance via the regulation of prolactin. These findings support the intriguing possibility that dysregulated PRL secretion may underlie the increased rate of reproductive health issues following prolonged circadian disruptions, including those observed in chronic shift workers (reviewed in Mahoney, 2010).

\section{CONCLUSION AND CONSIDERATIONS}

Given the pronounced impact of disruptions to circadian timing on female reproductive functioning and health, it is critical that a full understanding of the mechanisms underlying these processes be garnered. The SCN sits at the center of a hierarchy of temporal control, coordinating the activity of positive and negative upstream regulators of the HPG axis (Figure 4). In addition to receiving direct estrogenic feedback, the $\mathrm{SCN}$ also receive sex steroid feedback, indirectly, via estrogen-sensitive targets that communicate directly with the master pacemaker. Many reproductively relevant monosynaptic targets of the SCN express estrogen receptors, providing a further means of integration for circadian and estrogenic signaling necessary for optimal fecundity. Given the 
ubiquity of autonomous clock function in the CNS and periphery, it is likely that many targets of the SCN contain independent clocks to temporally modulate their network environment and further ensure ideal timing of reproductive events. The means by

\section{REFERENCES}

Adachi, S., Yamada, S., Takatsu, Y., Matsui, H., Kinoshita, M., Takase, K., Sugiura, H., Ohtaki, T., Matsumoto, H., Uenoyama, Y., Tsukamura, H., Inoue, K., Maeda, K. (2007). Involvement of anteroventral periventricular metastin/kisspeptin neurons in estrogen positive feedback action on luteinizing hormone release in female rats. J. Reprod. Dev. 53, 367-378.

Alleva, J. J., Waleski, M. V., and Alleva, F. R. (1971). A biological clock controlling the estrous cycle of the hamster. Endocrinology 88, 1368-1379.

Anderson, G. M., Relf, H. L., Rizwan, M. Z., and Evans, J. J. (2009). Central and peripheral effects of RFamiderelated peptide- 3 on luteinizing hormone and prolactin secretion in rats. Endocrinology 150, 1834-1840.

Bentley, G. E., Tsutsui, K., and Kriegsfeld, L. J. (2010). Recent studies of gonadotropin-inhibitory hormone (GnIH) in the mammalian hypothalamus, pituitary and gonads. Brain Res. 1364, 62-71.

Berson, D. M., Dunn, F. A., and Takao, M. (2002). Phototransduction by retinal ganglion cells that set the circadian clock. Science 295, 1070-1073.

Bethea, C. L., and Neill, J. D. (1979). Prolactin secretion after cervical stimulation of rats maintained in constant dark or constant light. Endocrinology 104, 870-876.

Boden, M. J., and Kennaway, D. J. (2006). Circadian rhythms and reproduction. Reproduction 132, 379-392.

Brann, D. W., and Mahesh, V. B. (1991). Endogenous excitatory amino acid involvement in the preovulatory and steroid-induced surge of gonadotropins in the female rat. Endocrinology 128, 1541-1547.

Chappell, P. E. (2005). Clocks and the black box: circadian influences on gonadotropin-releasing hormone secretion. J. Neuroendocrinol. 17, 119-130.

Chappell, P. E., White, R. S., and Mellon, P. L. (2003). Circadian gene expression regulates pulsatile gonadotropin-releasing hormone $(\mathrm{GnRH})$ secretory patterns in the hypothalamic GnRH-secreting GT1-7 cell line. J. Neurosci. 23, 11202-11213.

Chen, R., Schirmer, A., Lee, Y., Lee, H., Kumar, V., Yoo, S. H., Takahashi, J. S., and Lee, C. (2009). Rhythmic PER abundance defines a critical nodal point for negative feedback within the circadian clock mechanism. Mol. Cell 36, 417-430.

Christian, C. A., Mobley, J. L., and Moenter, S. M. (2005). Diurnal and estradiol-dependent changes in gonadotropin-releasing hormone neuron firing activity. Proc. Natl. Acad. Sci. U.S.A. 102, 15682-15687.

Christian, C. A., and Moenter, S. M. (2007). Estradiol induces diurnal shifts in GABA transmission to gonadotropin-releasing hormone neurons to provide a neural signal for ovulation. J. Neurosci. 27, 1913-1921.

Christian, C. A., and Moenter, S. M. (2008). Vasoactive intestinal polypeptide can excite gonadotropin-releasing hormone neurons in a manner dependent on estradiol and gated by time of day. Endocrinology 149, 3130-3136.

Christian, C. A., and Moenter, S. M. (2010). The neurobiology of preovulatory and estradiol-induced gonadotropin-releasing hormone surges. Endocr. Rev. 31, 544-577.

Christian, C. A., Pielecka-Fortuna, J., and Moenter, S. M. (2009). Estradiol suppresses glutamatergic transmission to gonadotropin-releasing hormone neurons in a model of negative feedback in mice. Biol. Reprod. 80, 1128-1135.

Clarkson, J., and Herbison, A. E. (2006). Postnatal development of kisspeptin neurons in mouse hypothalamus; sexual dimorphism and projections to gonadotropin-releasing hormone neurons. Endocrinology 147, 5817-5825.

d'Anglemont de Tassigny, X., Fagg, L. A., Carlton, M. B., and Colledge, W. H. (2008). Kisspeptin can stimulate gonadotropin-releasing hormone $(\mathrm{GnRH})$ release by a direct action at GnRH nerve terminals. Endocrinology 149, 3926-3932.

de la Iglesia, H. O., Blaustein, J. D., and Bittman, E. L. (1995). The suprachiasmatic area in the female hamster projects to neurons containing estrogen receptors and GnRH. Neuroreport 6, 1715-1722.

de la Iglesia, H. O., Blaustein, J. D., and Bittman, E. L. (1999). Oestrogen receptor-alpha-immunoreactive neurones project to the suprachiasmatic nucleus of the female Syrian

which other well-established regulators of the HPG axis synergize with these circadian controlled circuits to optimize female reproductive health represents and exciting and vital opportunity for further enquiry.

hamster. J. Neuroendocrinol. 11,481490.

de la Iglesia, H. O., Meyer, J., Carpino, A. Jr., and Schwartz, W. J. (2000). Antiphase oscillation of the left and right suprachiasmatic nuclei. Science 290, 799-801.

de la Iglesia, H. O., and Schwartz, W. J. (2006). Minireview: timely ovulation: circadian regulation of the female hypothalamo-pituitarygonadal axis. Endocrinology 147, 1148-1153.

de Roux, N., Genin, E., Carel, J. C., Matsuda, F., Chaussain, J. L., and Milgrom, E. (2003). Hypogonadotropic hypogonadism due to loss of function of the KiSS1derived peptide receptor GPR54. Proc. Natl. Acad. Sci. U.S.A. 100, 10972-10976.

DeVries, G. J., Buijs, R. M., Van Leeuwen, F. W., Caffe, A. R., and Swaab, D. F. (1985). The vasopressinergic innervation of the brain in normal and castrated rats. J. Comp. Neurol. 233, 236-254.

Dorling, A. A., Todman, M. G., Korach, K. S., and Herbison, A. E. (2003). Critical role for estrogen receptor alpha in negative feedback regulation of gonadotropin-releasing hormone mRNA expression in the female mouse. Neuroendocrinology 78, 204-209.

Ducret, E., Anderson, G. M., and Herbison, A. E. (2009). RFamiderelated peptide-3, a mammalian gonadotropin-inhibitory hormone ortholog, regulates gonadotropinreleasing hormone neuron firing in the mouse. Endocrinology 150, 2799-2804.

Egli, M., Bertram, R., Sellix, M. T., and Freeman, M. E. (2004). Rhythmic secretion of prolactin in rats: action of oxytocin coordinated by vasoactive intestinal polypeptide of suprachiasmatic nucleus origin. Endocrinology 145, 3386-3394.

Everett, J. W., and Sawyer, C. H. (1950). A 24-hour periodicity in the "LHrelease apparatus" of female rats, disclosed by barbiturate sedation. Endocrinology 47, 198-218.

Fitzgerald, K., and Zucker, I. (1976). Circadian organization of the estrous cycle of the golden hamster. Proc. Natl. Acad. Sci. U.S.A. 73, 2923-2927.

Freeman, M. E., Kanyicska, B., Lerant, A., and Nagy, G. (2000). Prolactin: structure, function, and regulation of secretion. Physiol. Rev. 80, 15231631.

Funabashi, T., Aiba, S., Sano, A., Shinohara, K., and Kimura, F. (1999). Intracerebroventricular injection of arginine-vasopressin $\mathrm{V} 1$ receptor antagonist attenuates the surge of luteinizing hormone and prolactin secretion in proestrus rats. Neurosci. Lett. 260, 37-40.

Funabashi, T., Shinohara, K., Mitsushima, D., and Kimura, F. (2000a). Estrogen increases argininevasopressin V1a receptor mRNA in the preoptic area of young but not of middle-aged female rats. Neurosci. Lett. 285, 205-208.

Funabashi, T., Shinohara, K., Mitsushima, D., and Kimura, F (2000b). Gonadotropin-releasing hormone exhibits circadian rhythm in phase with arginine-vasopressin in co-cultures of the female rat preoptic area and suprachiasmatic nucleus. J. Neuroendocrinol. 12, 521-528.

Funes, S., Hedrick, J. A., Vassileva, G., Markowitz, L., Abbondanzo, S., Golovko, A., Yang, S., Monsma, F. J., and Gustafson, E. L. (2003). The KiSS-1 receptor GPR54 is essential for the development of the murine reproductive system. Biochem. Biophys. Res. Commun. 312, 1357-1363.

Gerhold, L. M., Horvath, T. L., and Freeman, M. E. (2001). Vasoactive intestinal peptide fibers innervate neuroendocrine dopaminergic neurons. Brain Res. 919, 48-56.

Gerhold, L. M., Rosewell, K. L., and Wise, P. M. (2005). Suppression of vasoactive intestinal polypeptide in the suprachiasmatic nucleus leads to aging-like alterations in cAMP rhythms and activation of gonadotropin-releasing hormone neurons. J. Neurosci. 25, 62-67.

Gibson, E. M., Humber, S. A., Jain, S., Williams, W. P. III, Zhao, S., Bentley, G. E., Tsutsui, K., and Kriegsfeld, L. J. (2008). Alterations in RFamide-related peptide expression are coordinated with the preovulatory luteinizing hormone surge. Endocrinology 149, 4958-4969.

Gibson, M. J., Kokoris, G. J., and Silverman, A. J. (1988). Positive feedback in hypogonadal female mice with preoptic area brain transplants. Neuroendocrinology 48, 112-119. 
Gillespie, J. M., Chan, B. P., Roy, D., Cai, F., and Belsham, D. D. (2003). Expression of circadian rhythm genes in gonadotropin-releasing hormone-secreting GT1-7 neurons. Endocrinology 144, 5285-5292.

Gore, A. C., Wu, T. J., Rosenberg, J. J., and Roberts, J. L. (1996). Gonadotropin-releasing hormone and NMDA receptor gene expression and colocalization change during puberty in female rats. $J$. Neurosci. 16, 5281-5289.

Gottsch, M. L., Cunningham, M. J., Smith, J. T., Popa, S. M., Acohido, B. V., Crowley, W. F., Seminara, S., Clifton, D. K., and Steiner, R. A. (2004). A role for kisspeptins in the regulation of gonadotropin secretion in the mouse. Endocrinology 145, 4073-4077.

Grace, C. O., Fink, G., and Quinn, J. P. (1999). Characterization of potential regulatory elements within the rat arginine vasopressin proximal promoter. Neuropeptides 33, 81-90.

Gray, G. D., Soderstein, P., Tallentire, D., and Davidson, J. M. (1978). Effects of lesions in various structures of the suprachiasmatic-preoptic region on LH regulation and sexual behavior in female rats. Neuroendocrinology 25, 174-191.

Greives, T. J., Mason, A. O., Scotti, M. A., Levine, J., Ketterson, E. D., Kriegsfeld, L. J., and Demas, G. E. (2007). Environmental control of kisspeptin: implications for seasonal reproduction. Endocrinology 148, 1158-1166.

Gu, G. B., and Simerly, R. B. (1997). Projections of the sexually dimorphic anteroventral periventricular nucleus in the female rat. J. Comp. Neurol. 384, 142-164.

Guillaumond, F., Boyer, B., Becquet, D., Guillen, S., Kuhn, L., Garin, J., Belghazi, M., Bosler, O., Franc, J. L., and Francois-Bellan,A. M. (2011). Chromatin remodeling as a mechanism for circadian prolactin transcription: rhythmic NONO and SFPQ recruitment to HLTF. FASEB J. 25, 2740-2756.

Han, S. K., Gottsch, M. L., Lee, K. J., Popa, S. M., Smith, J. T., Jakawich, S. K., Clifton, D. K., Steiner, R. A., and Herbison, A. E. (2005). Activation of gonadotropin-releasing hormone neurons by kisspeptin as a neuroendocrine switch for the onset of puberty. J. Neurosci. 25, 11349-11356.

Harney, J. P., Scarbrough, K., Rosewell, K. L., and Wise, P. M. (1996). In vivo antisense antagonism of vasoactive intestinal peptide in the suprachiasmatic nuclei causes aging-like changes in the estradiolinduced luteinizing hormone and prolactin surges. Endocrinology 137, 3696-3701.

Hattar, S., Liao, H. W., Takao, M., Berson, D. M., and Yau, K. W. (2002). Melanopsin-containing retinal ganglion cells: architecture, projections, and intrinsic photosensitivity. Science 295, 1065-1070.

Herbison, A. E. (2008). Estrogen positive feedback to gonadotropinreleasing hormone (GnRH) neurons in the rodent: the case for the rostral periventricular area of the third ventricle (RP3V). Brain Res. Rev. 57, 277-287.

Herbison, A. E., and Theodosis, D. T. (1992a). Immunocytochemical identification of oestrogen receptors in preoptic neurones containing calcitonin gene-related peptide in the male and female rat. Neuroendocrinology 56, 761-764.

Herbison, A. E., and Theodosis, D. T. (1992b). Localization of oestrogen receptors in preoptic neurons containing neurotensin but not tyrosine hydroxylase, cholecystokinin or luteinizing hormone-releasing hormone in the male and female rat. Neuroscience 50, 283-298.

Hickok, J. R., and Tischkau, S. A. (2010). In vivo circadian rhythms in gonadotropin-releasing hormone neurons. Neuroendocrinology 91, 110-120.

Hinuma, S., Shintani, Y., Fukusumi, S., Iijima, N., Matsumoto, Y., Hosoya, M., Fujii, R., Watanabe, T., Kikuchi, K., Terao, Y., Yano, T., Yamamoto, T., Kawamata, Y., Habata, Y., Asada, M., Kitada, C., Kurokawa, T., Onda, H., Nishimura, O., Tanaka, M., Ibata, Y., and Fujino, M. (2000). New neuropeptides containing carboxyterminal RFamide and their receptor in mammals. Nat. Cell Biol. 2, 703-708.

Hoorneman, E. M., and Buijs, R. M. (1982). Vasopressin fiber pathways in the rat brain following suprachiasmatic nucleus lesioning. Brain Res. 243, 235-241.

Horvath, T. L., Cela, V., and Van Der Beek, E. M. (1998). Gender-specific apposition between vasoactive intestinal peptide-containing axons and gonadotrophinreleasing hormone-producing neurons in the rat. Brain Res. 795, 277-281.

Ibata, Y., Takahashi, Y., Okamura, H., Kawakami, F., Terubayashi, H., Kubo, T., and Yanaihara, N. (1989). Vasoactive intestinal peptide (VIP)-like immunoreactive neurons located in the rat suprachiasmatic nucleus receive a direct retinal projection. Neurosci. Lett. 97, 1-5.

Irwig, M. S., Fraley, G. S., Smith, J. T., Acohido, B. V., Popa, S. M., Cunningham, M. J., Gottsch, M L., Clifton, D. K., and Steiner, R. A. (2004). Kisspeptin activation of gonadotropin releasing hormone neurons and regulation of KiSS-1 mRNA in the male rat. Neuroendocrinology 80, 264-272.

Jarry, H., Leonhardt, S., Schwarze, T., and Wuttke, W. (1995). Preoptic rather than mediobasal hypothalamic amino acid neurotransmitter release regulates $\mathrm{GnRH}$ secretion during the estrogen-induced LH surge in the ovariectomized rat. Neuroendocrinology 62, 479-486.

Johnson, M. A., Tsutsui, K., and Fraley, G. S. (2007). Rat RFamide-related peptide-3 stimulates $\mathrm{GH}$ secretion, inhibits LH secretion, and has variable effects on sex behavior in the adult male rat. Horm. Behav. 51, 171-180.

Kalamatianos, T., Kallo, I., Goubillon, M. L., and Coen, C. W. (2004). Cellular expression of V1a vasopressin receptor mRNA in the female rat preoptic area: effects of oestrogen. $J$. Neuroendocrinol. 16, 525-533.

Kalsbeek, A., Buijs, R. M., Engelmann, M., Wotjak, C. T., and Landgraf, R. (1995). In vivo measurement of a diurnal variation in vasopressin release in the rat suprachiasmatic nucleus. Brain Res. 682, 75-82.

Kauffman, A. S. (2009). Sexual differentiation and the Kiss1 system: hormonal and developmental considerations. Peptides 30, 83-93.

Kauffman, A. S. (2010). Gonadal and nongonadal regulation of sex differences in hypothalamic Kiss 1 neurones. J. Neuroendocrinol. 22, 682691.

Kawakami, M., Arita, J., and Yoshioka, E. (1980). Loss of estrogeninduced daily surges of prolactin and gonadotropins by suprachiasmatic nucleus lesions in ovariectomized rats. Endocrinology 106, 1087-1092.

Keen, K. L., Wegner, F. H., Bloom, S. R., Ghatei, M. A., and Terasawa, E. (2008). An increase in kisspeptin54 release occurs with the pubertal increase in luteinizing hormonereleasing hormone- 1 release in the stalk-median eminence of female rhesus monkeys in vivo. Endocrinology 149, 4151-4157.

Khan, A. R., and Kauffman, A. S (2011). The role of kisspeptin and RFRP-3 neurons in the circadiantimed preovulatory luteinizing hormone surge. J. Neuroendocrinol. 24 131-143.
Kinoshita, M., Tsukamura, H., Adachi, S., Matsui, H., Uenoyama, Y., Iwata, K., Yamada, S., Inoue, K., Ohtaki, T., Matsumoto, H., and Maeda, K. (2005). Involvement of central metastin in the regulation of preovulatory luteinizing hormone surge and estrous cyclicity in female rats. Endocrinology 146, 4431-4436.

Kotani, M., Detheux, M., Vandenbogaerde, A., Communi, D., Vanderwinden, J. M., Le Poul, E. Brezillon, S., Tyldesley, R., SuarezHuerta, N., Vandeput, F., Blanpain, C., Schiffmann, S. N., Vassart, G., and Parmentier, M. (2001). The metastasis suppressor gene KiSS1 encodes kisspeptins, the natural ligands of the orphan G proteincoupled receptor GPR54. J. Biol. Chem. 276, 34631-34636.

Krajnak, K., Rosewell, K. L., and Wise, P. M. (2001). Fos-induction in gonadotropin-releasing hormone neurons receiving vasoactive intestinal polypeptide innervation is reduced in middle-aged female rats. Biol. Reprod. 64 , 1160-1164.

Kriegsfeld, L. J., Gibson, E. M., Williams, W. P. III, Zhao, S., Mason, A. O., Bentley, G. E., and Tsutsui, K. (2010). The roles of RFamide-related peptide- 3 in mammalian reproductive function and behaviour. J. Neuroendocrinol. 22, 692-700.

Kriegsfeld, L. J., Korets, R., and Silver, R. (2003). Expression of the circadian clock gene period 1 in neuroendocrine cells: an investigation using mice with a Per1::GFP transgene. Eur. J. Neurosci. 17, 212-220.

Kriegsfeld, L. J., Leak, R. K., Yackulic, C. B., Lesauter, J., and Silver, R. (2004). Organization of suprachiasmatic nucleus projections in Syrian hamsters (Mesocricetus auratus): an anterograde and retrograde analysis. J. Comp. Neurol. 468, 361-379.

Kriegsfeld, L. J., Mei, D. F., Bentley, G. E., Ubuka, T., Mason, A. O., Inoue, K., Ukena, K., Tsutsui, K., and Silver, R. (2006). Identification and characterization of a gonadotropin-inhibitory system in the brains of mammals. Proc. Natl. Acad. Sci. U.S.A. 103, 2410-2415.

Kriegsfeld, L. J., and Silver, R. (2006). The regulation of neuroendocrine function: timing is everything. Horm. Behav. 49, 557-574.

Kriegsfeld, L. J., Silver, R., Gore, A. C., and Crews, D. (2002). Vasoactive intestinal polypeptide contacts on gonadotropin-releasing 
hormone neurones increase following puberty in female rats. $\mathrm{J}$. Neuroendocrinol. 14, 685-690.

Kruijver, F. P., and Swaab, D. F. (2002). Sex hormone receptors are present in the human suprachiasmatic nucleus. Neuroendocrinology 75, 296-305.

Lavery, D. J., Lopez-Molina, L., Margueron, R., Fleury-Olela, F., Conquet, F., Schibler, U., and Bonfils, C. (1999). Circadian expression of the steroid 15 alphahydroxylase (Cyp2a4) and coumarin 7-hydroxylase (Cyp2a5) genes in mouse liver is regulated by the PAR leucine zipper transcription factor DBP. Mol. Cell. Biol. 19, 6488-6499.

Le, W. W., Berghorn, K. A., Rassnick, S., and Hoffman, G. E. (1999). Periventricular preoptic area neurons coactivated with luteinizing hormone (LH)-releasing hormone (LHRH) neurons at the time of the LH surge are LHRH afferents. Endocrinology $140,510-519$.

Lee, J. H., Miele, M. E., Hicks, D. J., Phillips, K. K., Trent, J. M., Weissman, B. E., and Welch, D. R. (1996). KiSS-1, a novel human malignant melanoma metastasissuppressor gene. J. Natl. Cancer Inst. 88, 1731-1737.

Legan, S. J., Coon, G. A., and Karsch, F. J. (1975). Role of estrogen as initiator of daily LH surges in the ovariectomized rat. Endocrinology 96, 50-56.

Legan, S. J., and Karsch, F. J. (1975). A daily signal for the LH surge in the rat. Endocrinology 96, 57-62.

Lehman, M. N., Coolen, L. M., and Goodman, R. L. (2010a). Minireview: kisspeptin/neurokinin $\mathrm{B}$ /dynorphin (KNDy) cells of the arcuate nucleus: a central node in the control of gonadotropin-releasing hormone secretion. Endocrinology 151, 3479-3489.

Lehman, M. N., Merkley, C. M., Coolen, L. M., and Goodman, R. L. (2010b). Anatomy of the kisspeptin neural network in mammals. Brain Res. $1364,90-102$.

Lehman, M. N., Silver, R., Gladstone, W. R., Kahn, R. M., Gibson, M., and Bittman, E. L. (1987). Circadian rhythmicity restored by neural transplant. Immunocytochemical characterization of the graft and its integration with the host brain. J Neurosci. 7, 1626-1638.

Leranth, C., Maclusky, N. J., Sakamoto, H., Shanabrough, M., and Naftolin, F. (1985). Glutamic acid decarboxylase-containing axons synapse on LHRH neurons in the rat medial preoptic area. Neuroendocrinology 40, 536-539.

Lopez, F. J., Donoso, A. O., and NegroVilar, A. (1990). Endogenous excitatory amino acid neurotransmission regulates the estradiol-induced LH surge in ovariectomized rats. Endocrinology 126, 1771-1773.

Lowrey, P. L., Shimomura, K., Antoch, M. P., Yamazaki, S., Zemenides, P. D., Ralph,M. R., Menaker, M., and Takahashi, J. S. (2000). Positional syntenic cloning and functional characterization of the mammalian circadian mutation tau. Science 288, 483-492.

Luque, R. M., Cordoba-Chacon, J., Gahete, M. D., Navarro, V. M., Tena-Sempere, M., Kineman, R. D., and Castano, J. P. (2011). Kisspeptin regulates gonadotroph and somatotroph function in nonhuman primate pituitary via common and distinct signaling mechanisms. Endocrinology 152, 957-966.

Mahoney, M. M. (2010). Shift work, jet lag, and female reproduction. Int. J. endocrinol. 2010, 813764.

Mahoney, M. M., Sisk, C., Ross, H. E., and Smale, L. (2004). Circadian regulation of gonadotropin-releasing hormone neurons and the preovulatory surge in luteinizing hormone in the diurnal rodent, Arvicanthis niloticus, and in a nocturnal rodent, Rattus norvegicus. Biol. Reprod. 70, 1049-1054.

Matagne, V., Kim, J. G., Ryu, B. J., Hur, M. K., Kim, M. S., Kim, K., Park, B. S., Damante, G., Smiley, G., Lee, B. J., and Ojeda, S. R. (2012). TTF1, a homeodomain containing transcription factor, contributes to regulating periodic oscillations in $\mathrm{GnRH}$ gene expression. J. Neuroendocrinol. (in press).

Matsui, H., Takatsu, Y., Kumano, S., Matsumoto, H., and Ohtaki, T. (2004). Peripheral administration of metastin induces marked gonadotropin release and ovulation in the rat. Biochem. Biophys. Res. Commun. 320, 383-388.

Mayer, C., and Boehm, U. (2011). Female reproductive maturation in the absence of kisspeptin/GPR54 signaling. Nat. Neurosci. 14, 704-710.

Maywood, E. S., O'Neill, J. S., Chesham, J. E., and Hastings, M. H. (2007). Minireview: the circadian clockwork of the suprachiasmatic nuclei - analysis of a cellular oscillator that drives endocrine rhythms. Endocrinology 148, 5624-5634.

Meyer-Bernstein, E. L., Jetton, A. E., Matsumoto, S. I., Markuns, J. F.,
Lehman, M. N., and Bittman, E. L. (1999). Effects of suprachiasmatic transplants on circadian rhythms of neuroendocrine function in golden hamsters. Endocrinology 140, 207-218.

Miller, B. H., Olson, S. L., Turek, F. W., Levine, J. E., Horton, T. H. and Takahashi, J. S. (2004). Circadian clock mutation disrupts estrous cyclicity and maintenance of pregnancy. Curr. Biol. 14, 1367-1373.

Milligan, S. R., and Finn, C. A. (1997). Minimal progesterone support required for the maintenance of pregnancy in mice. Hum. Reprod. 12, 602-607.

Mohawk, J. A., and Takahashi, J. S. (2011). Cell autonomy and synchrony of suprachiasmatic nucleus circadian oscillators. Trends $\mathrm{Neu}$ rosci. (in press).

Molnar, C. S., Kallo, I., Liposits, Z., and Hrabovszky, E. (2011). Estradiol down-regulates RF-amiderelated peptide (RFRP) expression in the mouse hypothalamus. Endocrinology 152, 1684-1690.

Moore, R. Y., and Eichler, V. B. (1972). Loss of a circadian adrenal corticosterone rhythm following suprachiasmatic lesions in the rat. Brain Res. 42 , 201-206.

Moore, R. Y., Speh, J. C., and Leak, R. K. (2002). Suprachiasmatic nucleus organization. Cell Tissue Res. 309, 89-98.

Morin, L. P., and Allen, C. N. (2006). The circadian visual system, 2005. Brain Res. Rev. 51, 1-60.

Muir, A. I., Chamberlain, L., Elshourbagy, N. A., Michalovich, D., Moore, D. J., Calamari, A., Szekeres, P. G., Sarau, H. M., Chambers, J. K., Murdock, P., Steplewski, K., Shabon, U., Miller, J. E., Middleton, S. E., Darker, J. G., Larminie, C. G., Wilson, S., Bergsma, D. J., Emson, P., Faull, R., Philpott, K. L., and Harrison, D. C. (2001). AXOR12, a novel human $\mathrm{G}$ protein-coupled receptor, activated by the peptide KiSS-1. J. Biol. Chem. 276, 28969-28975.

Munoz, E., Brewer, M., and Baler, R. (2002). Circadian transcription. Thinking outside the E-box. J. Biol. Chem. 277, 36009-36017.

Murakami, M., Matsuzaki, T., Iwasa, T., Yasui, T., Irahara, M., Osugi, T., and Tsutsui, K. (2008). Hypophysiotropic role of RFamide-related peptide-3 in the inhibition of LH secretion in female rats. $J$. Endocrinol. 199, 105-112.

Navarro, V. M., Castellano, J. M., Fernandez-Fernandez, R., Tovar, S., Roa, J., Mayen, A., Barreiro, M. L.,
Casanueva, F. F., Aguilar, E., Dieguez, C., Pinilla, L., and Tena-Sempere, M. (2005a). Effects of KiSS-1 peptide, the natural ligand of GPR54, on follicle-stimulating hormone secretion in the rat. Endocrinology 146, 1689-1697.

Navarro, V. M., Castellano, J. M., Fernandez-Fernandez, R., Tovar, S., Roa, J., Mayen, A., Nogueiras, R., Vazquez, M. J., Barreiro, M. L., Magni, P., Aguilar, E., Dieguez, C., Pinilla, L., and Tena-Sempere, M. (2005b). Characterization of the potent luteinizing hormonereleasing activity of KiSS-1 peptide, the natural ligand of GPR54. Endocrinology 146, 156-163.

Nequin, L. G., Alvarez, J., and Schwartz, N. B. (1975). Steroid control of gonadotropin release. J. Steroid Biochem. 6, 1007-1012.

Nunez, A. A., and Stephan, F. K. (1977). The effects of hypothalamic knife cuts on drinking rhythms and the estrus cycle of the rat. Behav. Biol. 20, 224-234.

Ohtaki, T., Shintani, Y., Honda, S., Matsumoto, H., Hori, A., Kanehashi, K., Terao, Y., Kumano, S., Takatsu, Y., Masuda, Y., Ishibashi, Y., Watanabe, T., Asada, M., Yamada, T., Suenaga, M., Kitada, C., Usuki, S., Kurokawa, T., Onda, H., Nishimura, O., and Fujino, M. (2001). Metastasis suppressor gene KiSS-1 encodes peptide ligand of a G-proteincoupled receptor. Nature 411, 613-617.

Olcese, J., Domagalski, R., Bednorz, A., Weaver, D. R., Urbanski, H. F., Reuss, S., and Middendorff, R. (2003). Expression and regulation of mPerl in immortalized GnRH neurons. Neuroreport 14, 613-618.

Ostrowski, N. L., Lolait, S. J., and Young, W. S. III. (1994). Cellular localization of vasopressin V1a receptor messenger ribonucleic acid in adult male rat brain, pineal, and brain vasculature. Endocrinology 135, 1511-1528.

Ottem, E. N., Godwin, J. G., Krishnan, S., and Petersen, S. L. (2004). Dualphenotype GABA/glutamate neurons in adult preoptic area: sexual dimorphism and function. J. Neurosci. 24, 8097-8105.

Palm, I. F., Van Der Beek, E. M., Swarts, H. J., Van Der Vliet, J., Wiegant, V. M., Buijs, R. M., and Kalsbeek, A. (2001a). Control of the estradiol-induced prolactin surge by the suprachiasmatic nucleus. Endocrinology 142, 2296-2302.

Palm, I. F., Van Der Beek, E. M., Wiegant, V. M., Buijs, R. M., and Kalsbeek, A. (2001b). The stimulatory 
effect of vasopressin on the luteinizing hormone surge in ovariectomized, estradiol-treated rats is time-dependent. Brain Res. 901, 109-116.

Palm, I. F., Van Der Beek, E. M., Wiegant, V. M., Buijs, R. M., and Kalsbeek, A. (1999). Vasopressin induces a luteinizing hormone surge in ovariectomized, estradiol-treated rats with lesions of the suprachiasmatic nucleus. Neuroscience 93, 659-666.

Pan, J. T., and Gala, R. R. (1985). Central nervous system regions involved in the estrogen-induced afternoon prolactin surge. II. Implantation studies. Endocrinology 117, 388-395.

Panda, S., Sato, T. K., Castrucci, A. M., Rollag, M. D., Degrip, W. J., Hogenesch, J. B., Provencio, I., and Kay, S. A. (2002). Melanopsin (Opn4) requirement for normal light-induced circadian phase shifting. Science 298, 2213-2216.

Petersen, S. L., and Barraclough, C. A. (1989). Suppression of spontaneous LH surges in estrogen-treated ovariectomized rats by microimplants of antiestrogens into the preoptic brain. Brain Res. 484, 279-289.

Petersen, S. L., Ottem, E. N., and Carpenter, C. D. (2003). Direct and indirect regulation of gonadotropinreleasing hormone neurons by estradiol. Biol. Reprod. 69, 1771-1778.

Pielecka-Fortuna, J., and Moenter, S. M. (2010). Kisspeptin increases gamma-aminobutyric acidergic and glutamatergic transmission directly to gonadotropin-releasing hormone neurons in an estradioldependent manner. Endocrinology 151, 291-300.

Pineda, R., Aguilar, E., Pinilla, L., and Tena-Sempere, M. (2010a). Physiological roles of the kisspeptin/GPR54 system in the neuroendocrine control of reproduction. Prog. Brain Res. 181, 55-77.

Pineda, R., Garcia-Galiano, D., SanchezGarrido, M. A., Romero, M., RuizPino, F., Aguilar, E., Dijcks, F. A., Blomenrohr, M., Pinilla, L., Van Noort, P. I., and Tena-Sempere, M. (2010b). Characterization of the potent gonadotropin-releasing activity of RF9, a selective antagonist of RF-amide-related peptides and neuropeptide FF receptors: physiological and pharmacological implications. Endocrinology 151, 1902-1913.

Poletini, M. O., Kennett, J. E., Mckee, D. T., and Freeman, M. E. (2010). Central clock regulates the cervically stimulated prolactin surges by modulation of dopamine and vasoactive intestinal polypeptide release in ovariectomized rats. $\mathrm{Neu}$ roendocrinology 91, 179-188.

Poletini, M. O., Mckee, D. T., Kennett, J. E., Doster, J., and Freeman, M. E. (2007). Knockdown of clock genes in the suprachiasmatic nucleus blocks prolactin surges and alters FRA expression in the locus coeruleus of female rats. Am. J. Physiol. Endocrinol. Metab. 293, E1325E1334.

Provencio, I., Rollag, M. D., and Castrucci, A. M. (2002). Photoreceptive net in the mammalian retina. This mesh of cells may explain how some blind mice can still tell day from night. Nature 415, 493.

Ralph, M. R., Foster, R. G., Davis, F. C., and Menaker, M. (1990). Transplanted suprachiasmatic nucleus determines circadian period. Science 247, 975-978.

Reppert, S. M., and Weaver, D. R. (2002). Coordination of circadian timing in mammals. Nature 418, 935-941.

Resuehr, D., Wildemann, U., Sikes, H., and Olcese, J. (2007). E-box regulation of gonadotropin-releasing hormone $(\mathrm{GnRH})$ receptor expression in immortalized gonadotrope cells. Mol. Cell. Endocrinol. 278, 36-43.

Revel, F. G., Saboureau, M., MassonPevet, M., Pevet, P., Mikkelsen, J. D., and Simonneaux, V. (2006). Kisspeptin mediates the photoperiodic control of reproduction in hamsters. Curr. Biol. 16, 1730-1735.

Ripperger, J. A., and Schibler, U. (2006). Rhythmic CLOCK-BMAL1 binding to multiple E-box motifs drives circadian Dbp transcription and chromatin transitions. Nat. Genet. 38, 369-374.

Rizwan, M. Z., Porteous, R., Herbison, A. E., and Anderson, G. M. (2009). Cells expressing RFamiderelated peptide- $1 / 3$, the mammalian gonadotropin-inhibitory hormone orthologs, are not hypophysiotropic neuroendocrine neurons in the rat. Endocrinology 150, 1413-1420.

Robertson, J. L., Clifton, D. K., De La Iglesia, H. O., Steiner, R. A., and Kauffman, A. S. (2009). Circadian regulation of Kiss1 neurons: implications for timing the preovulatory gonadotropin-releasing hormone/luteinizing hormone surge. Endocrinology 150, 3664-3671.

Ronnekleiv, O. K., and Kelly, M. J. (1988). Plasma prolactin and luteinizing hormone profiles during the estrous cycle of the female rat: effects of surgically induced persistent estrus. Neuroendocrinology 47, 133-141.
Roseweir, A. K., Kauffman, A. S., Smith, J. T., Guerriero, K. A., Morgan, K., Pielecka-Fortuna, J., Pineda, R., Gottsch, M. L., Tena-Sempere, M., Moenter, S. M., Terasawa, E. Clarke, I. J., Steiner, R. A., and Millar, R. P. (2009). Discovery of potent kisspeptin antagonists delineate physiological mechanisms of gonadotropin regulation. J. Neurosci. 29, 3920-3929.

Ruby, N. F., Brennan, T. J., Xie, X., Cao, V., Franken, P., Heller, H. C., and O'Hara, B. F. (2002). Role of melanopsin in circadian responses to light. Science 298, 2211-2213.

Sarkar, D. K., Chiappa, S. A., Fink, G., and Sherwood, N. M. (1976). Gonadotropin-releasing hormone surge in pro-oestrous rats. Nature 264, 461-463.

Schwartz, W. J., Coleman, R. J., and Reppert, S. M. (1983). A daily vasopressin rhythm in rat cerebrospinal fluid. Brain Res. 263, 105-112.

Sellix, M. T., Egli, M., Poletini, M. O., Mckee, D. T., Bosworth, M. D., Fitch, C. A., and Freeman, M. E. (2006). Anatomical and functional characterization of clock gene expression in neuroendocrine dopaminergic neurons. Am. J. Physiol. Regul. Integr. Comp. Physiol. 290, R1309-R1323.

Seminara, S. B., Messager, S., Chatzidaki, E. E., Thresher, R. R., Acierno, J. S. Jr., Shagoury, J. K., Bo-Abbas, Y., Kuohung, W., Schwinof, K. M., Hendrick, A. G., Zahn, D., Dixon, J., Kaiser, U. B., Slaugenhaupt, S. A., Gusella, J. F., O’Rahilly, S., Carlton, M. B., Crowley, W. F. Jr., Aparicio, S. A., and Colledge, W. H. (2003). The GPR54 gene as a regulator of puberty. N. Engl. J. Med. 349, 1614-1627.

Shima, N., Yamaguchi, Y., and Yuri, K. (2003). Distribution of estrogen receptor beta mRNAcontaining cells in ovariectomized and estrogen-treated female rat brain. Anat. Sci. Int. 78, 85-97.

Shinohara, K., Honma, S., Katsuno, Y., Abe, H., and Honma, K. (1994). Circadian rhythms in the release of vasoactive intestinal polypeptide and arginine-vasopressin in organotypic slice culture of rat suprachiasmatic nucleus. Neurosci. Lett. 170, 183-186.

Shughrue, P. J., Lane, M. V., and Merchenthaler, I. (1997). Comparative distribution of estrogen receptor-alpha and -beta mRNA in the rat central nervous system. $J$. Comp. Neurol. 388, 507-525.

Silver, R., Lehman, M. N., Gibson, M., Gladstone, W. R., and Bittman, E. L. (1990). Dispersed cell suspensions of fetal SCN restore circadian rhythmicity in SCN-lesioned adult hamsters. Brain Res. 525, 45-58.

Silver, R., Lesauter, J., Tresco, P. A., and Lehman, M. N. (1996). A diffusible coupling signal from the transplanted suprachiasmatic nucleus controlling circadian locomotor rhythms. Nature 382, 810-813.

Silverman, A. J., Zimmerman, E. A., Gibson, M. J., Perlow, M. J., Charlton, H. M., Kokoris, G. J., and Krieger, D. T. (1985). Implantation of normal fetal preoptic area into hypogonadal mutant mice: temporal relationships of the growth of gonadotropin-releasing hormone neurons and the development of the pituitary/testicular axis. Neuroscience 16, 69-84.

Sliwowska, J. H., Billings, H. J., Goodman, R. L., and Lehman, M. N. (2006). Immunocytochemical colocalization of GABA-B receptor subunits in gonadotropin-releasing hormone neurons of the sheep. Neuroscience 141, 311-319.

Smith, J. T., and Clarke, I. J. (2010). Gonadotropin inhibitory hormone function in mammals. Trends Endocrinol. Metab. 21, 255-260.

Smith, J. T., Coolen, L. M., Kriegsfeld, L. J., Sari, I. P., Jaafarzadehshirazi, M. R., Maltby, M., Bateman, K., Goodman, R. L., Tilbrook, A. J., Ubuka, T., Bentley, G. E., Clarke, I. J., and Lehman, M. N. (2008). Variation in kisspeptin and RFamide-related peptide (RFRP) expression and terminal connections to gonadotropinreleasing hormone neurons in the brain: a novel medium for seasonal breeding in the sheep. Endocrinology 149, 5770-5782.

Smith, J. T., Cunningham, M. J., Rissman, E. F., Clifton, D. K., and Steiner, R. A. (2005a). Regulation of Kiss 1 gene expression in the brain of the female mouse. Endocrinology 146, 3686-3692.

Smith, J. T., Dungan, H. M., Stoll, E. A., Gottsch, M. L., Braun, R. E., Eacker, S. M., Clifton, D. K., and Steiner, R. A. (2005b). Differential regulation of KiSS-1 mRNA expression by sex steroids in the brain of the male mouse. Endocrinology 146, 2976-2984.

Smith, J. T., Popa, S. M., Clifton, D. K., Hoffman, G. E., and Steiner, R. A. (2006). Kiss1 neurons in the forebrain as central processors for generating the preovulatory luteinizing hormone surge. J. Neurosci. 26, 6687-6694.

Smith, M. J., Jiennes, L., and Wise, P. M. (2000). Localization of the VIP2 receptor protein on $\mathrm{GnRH}$ neurons 
in the female rat. Endocrinology 141, 4317-4320.

Spergel, D. J., Kruth, U., Hanley, D. F., Sprengel, R., and Seeburg, P. H. (1999). GABA- and glutamate-activated channels in green fluorescent protein-tagged gonadotropin-releasing hormone neurons in transgenic mice. $J$. Neurosci. 19, 2037-2050.

Stephan, F. K., and Zucker, I. (1972). Circadian rhythms in drinking behavior and locomotor activity of rats are eliminated by hypothalamic lesions. Proc. Natl. Acad. Sci. U.S.A. 69, 1583-1586

Sullivan, S. D., and Moenter, S. M. (2004). Gamma-aminobutyric acid neurons integrate and rapidly transmit permissive and inhibitory metabolic cues to gonadotropin-releasing hormone neurons. Endocrinology 145, 1194-1202.

Swann, J. M., and Turek, F. W. (1985). Multiple circadian oscillators regulate the timing of behavioral and endocrine rhythms in female golden hamsters. Science 228, 898-900.

Tanaka, M., Ichitani, Y., Okamura, H., Tanaka, Y., and Ibata, Y. (1993). The direct retinal projection to VIP neuronal elements in the rat SCN. Brain Res. Bull. 31, 637-640.

Tavakoli-Nezhad, M., and Schwartz, W. J. (2005). c-Fos expression in the brains of behaviorally "split" hamsters in constant light: calling attention to a dorsolateral region of the suprachiasmatic nucleus and the medial division of the lateral habenula. J. Biol. Rhythms 20, 419-429.

Teclemariam-Mesbah, R., Kalsbeek, A., Pevet, P., and Buijs, R. M. (1997). Direct vasoactive intestinal polypeptide-containing projection from the suprachiasmatic nucleus to spinal projecting hypothalamic paraventricular neurons. Brain Res. 748, 71-76.

Tonsfeldt, K. J., Goodall, C. P., Latham, K. L., and Chappell, P. E. (2011). Oestrogen induces rhythmic expression of the Kisspeptin1 receptor GPR54 in hypothalamic gonadotrophin-releasing hormonesecreting GT1-7 cells. J. Neuroendocrinol. 23, 823-830.

Tsutsui, K., Bentley, G. E., Kriegsfeld, L. J., Osugi, T., Seong, J. Y., and Vaudry, H. (2010). Discovery and evolutionary history of gonadotrophin-inhibitory hormone and kisspeptin: new key neuropeptides controlling reproduction. $J$. Neuroendocrinol. 22, 716-727.

Tsutsui, K., Saigoh, E., Ukena, K., Teranishi, H., Fujisawa, Y., Kikuchi, M., Ishii, S., and Sharp, P. J. (2000). A novel avian hypothalamic peptide inhibiting gonadotropin release. Biochem. Biophys. Res. Commun. 275, 661-667.

Ueda, H. R., Hayashi, S., Chen, W., Sano, M., Machida, M., Shigeyoshi, Y., Iino, M., and Hashimoto, S. (2005). System-level identification of transcriptional circuits underlying mammalian circadian clocks. Nat. Genet. 37, 187-192.

van der Beek, E. M., Horvath, T. L., Wiegant, V. M., Van Den Hurk, R., and Buijs, R. M. (1997). Evidence for a direct neuronal pathway from the suprachiasmatic nucleus to the gonadotropin-releasing hormone system: combined tracing and light and electron microscopic immunocytochemical studies. J. Comp. Neurol. 384, 569-579.

van der Beek, E. M., Van Oudheusden, H. J., Buijs, R. M., Van Der Donk, H. A., Van Den Hurk, R., and Wiegant, V. M. (1994). Preferential induction of c-fos immunoreactivity in vasoactive intestinal polypeptideinnervated gonadotropin-releasing hormone neurons during a steroidinduced luteinizing hormone surge in the female rat. Endocrinology 134, 2636-2644.

Vida, B., Deli, L., Hrabovszky, E., Kalamatianos, T., Caraty, A., Coen, C. W., Liposits, Z., and Kallo, I. (2010). Evidence for suprachiasmatic vasopressin neurons innervating kisspeptin neurons in the rostral periventricular area of the mouse brain: regulation by oestrogen. $J$. Neuroendocrinol. 22, 1032-1039.

Vida, B., Hrabovszky, E., Kalamatianos, T., Coen, C. W., Liposits, Z., and Kallo, I. (2008). Oestrogen receptor alpha and beta immunoreactive cells in the suprachiasmatic nucleus of mice: distribution, sex differences and regulation by gonadal hormones. J. Neuroendocrinol. 20, 12701277.

Wang, G. Q., Du, Y. Z., and Tong, J. (2007). Daily oscillation and photoresponses of clock gene, clock, and clock-associated gene, arylalkylamine $\mathrm{N}$-acetyltransferase gene transcriptions in the rat pineal gland. Chronobiol. Int. 24, 9-20.

Watson, R. E. Jr., Langub, M. C. Jr., Engle, M. G., and Maley, B. E. (1995). Estrogen-receptive neurons in the anteroventral periventricular nucleus are synaptic targets of the suprachiasmatic nucleus and peri-suprachiasmatic region. Brain Res. 689, 254-264.

Watts, A. G., and Swanson, L. W. (1987). Efferent projections of the suprachiasmatic nucleus: II. Studies using retrograde transport of fluorescent dyes and simultaneous peptide immunohistochemistry in the rat. J. Comp. Neurol. 258, 230-252.

Wiegand, S. J., and Terasawa, E. (1982). Discrete lesions reveal functional heterogeneity of suprachiasmatic structures in regulation of gonadotropin secretion in the female rat. Neuroendocrinology 34 395-404.

Wiegand, S. J., Terasawa, E., Bridson, W. E., and Goy, R. W. (1980). Effects of discrete lesions of preoptic and suprachiasmatic structures in the female rat. Alterations in the feedback regulation of gonadotropin secretion. Neuroendocrinology 31 147-157.

Williams, W. P. III, Jarjisian, S. G., Mikkelsen, J. D., and Kriegsfeld, L. J. (2011). Circadian control of kisspeptin and a gated GnRH response mediate the preovulatory luteinizing hormone surge. Endocrinology 152, 595-606.

Wilson, M. E., Rosewell, K. L., Kashon, M. L., Shughrue, P. J., Merchenthaler, I., and Wise, P. M. (2002). Age differentially influences estrogen receptor-alpha (ERalpha) and estrogen receptor-beta (ERbeta) gene expression in specific regions of the rat brain. Mech. Ageing Dev. 123 593-601.

Wintermantel, T. M., Campbell, R. E., Porteous, R., Bock, D., Grone, H. J., Todman, M. G., Korach, K. S. Greiner, E., Perez, C. A., Schutz, G., and Herbison, A. E. (2006). Definition of estrogen receptor pathway critical for estrogen positive feedback to gonadotropin-releasing hormone neurons and fertility. Neuron 52, 271-280.

Wu, M., Dumalska, I., Morozova, E., Van Den Pol, A. N., and Alreja, M.
(2009). Gonadotropin inhibitory hormone inhibits basal forebrain vGluT2-gonadotropin-releasing hormone neurons via a direct postsynaptic mechanism. J. Physiol. (Lond.) 587, 1401-1411.

Yan, L., Foley, N. C., Bobula, J. M., Kriegsfeld, L. J., and Silver, R. (2005). Two antiphase oscillations occur in each suprachiasmatic nucleus of behaviorally split hamsters. J. Neurosci. 25, 9017-9026.

Yin, H., Ukena, K., Ubuka, T., and Tsutsui, K. (2005). A novel G proteincoupled receptor for gonadotropininhibitory hormone in the Japanese quail (Coturnix japonica): identification, expression and binding activity. J. Endocrinol. 184, 257-266.

Yogev, L., and Terkel, J. (1980). Effects of photoperiod, absence of photic cues, and suprachiasmatic nucleus lesions on nocturnal prolactin surges in pregnant and pseudopregnant rats. Neuroendocrinology 31, 26-33.

Zhao, S., and Kriegsfeld, L. J. (2009). Daily changes in GT1-7 cell sensitivity to GnRH secretagogues that trigger ovulation. Neuroendocrinology $89,448-457$.

Conflict of Interest Statement: The authors declare that the research was conducted in the absence of any commercial or financial relationships that could be construed as a potential conflict of interest.

Received: 10 December 2011; accepted: 13 April 2012; published online: 21 May 2012.

Citation: Williams III WP and Kriegsfeld LJ (2012) Circadian control of neuroendocrine circuits regulating female reproductive function. Front. Endocrin. 3:60. doi: 10.3389/fendo.2012.00060

This article was submitted to Frontiers in Genomic Endocrinology, a specialty of Frontiers in Endocrinology.

Copyright (c) 2012 Williams III and Kriegsfeld. This is an open-access article distributed under the terms of the Creative Commons Attribution Non Commercial License, which permits noncommercial use, distribution, and reproduction in other forums, provided the original authors and source are credited. 